\title{
WestVirginiaUniversity
}

THE RESEARCH REPOSITORY @ WVU

Graduate Theses, Dissertations, and Problem Reports

2014

\section{Does cultural self-awareness alter instructional design decisions?}

Antoinette Hando

West Virginia University

Follow this and additional works at: https://researchrepository.wvu.edu/etd

\section{Recommended Citation}

Hando, Antoinette, "Does cultural self-awareness alter instructional design decisions?" (2014). Graduate Theses, Dissertations, and Problem Reports. 645.

https://researchrepository.wvu.edu/etd/645

This Dissertation is protected by copyright and/or related rights. It has been brought to you by the The Research Repository @ WVU with permission from the rights-holder(s). You are free to use this Dissertation in any way that is permitted by the copyright and related rights legislation that applies to your use. For other uses you must obtain permission from the rights-holder(s) directly, unless additional rights are indicated by a Creative Commons license in the record and/ or on the work itself. This Dissertation has been accepted for inclusion in WVU Graduate Theses, Dissertations, and Problem Reports collection by an authorized administrator of The Research Repository @ WVU.

For more information, please contact researchrepository@mail.wvu.edu. 
DOES CULTURAL SELF-AWARENESS ALTER INSTRUCTIONAL DESIGN DECISIONS?

\author{
by \\ Antoinette Hando \\ Dissertation submitted to the College of Education and Human Services \\ at West Virginia University \\ in partial fulfillment of the requirements \\ for the degree of
} Doctor of Education
in
Department of Learning Sciences and Human Development

Terence C. Ahern, Ph.D., Chair

Daniel Hursh, Ph.D.

Neal Shambaugh, Ph.D.

Ugur Kale, Ph.D.

Carol Zwickel, Ph.D.

Instructional Design and Technology

Morgantown, West Virginia 2014

Keywords: Instructional Design, Hofstede's Model of Cultural Dimensions, Crosscultural instructional design

Copyright 2014 Hando 
Abstract

\section{DOES CULTURAL SELF-AWARENESS ALTER INSTRUCTIONAL DESIGN DECISIONS?}

\section{By Antoinette Hando}

This project looks at the influence background culture has on instructional designers. Current research supports the hypothesis that background culture affects learning preferences. This study approaches cultural background from the instructional designers' point of view. Using Hofstede's Model of Cultural Dimensions as a tool for understanding how culture influences our expectations in a classroom setting a survey was sent to subjects from various cultures to see if their design style correlated to the ranking given by Hofstede. The results were that background culture influenced the experiences of the participants and could be related to Hofstede's Model of Cultural Dimensions. 


\section{DEDICATION}

The author wishes to dedicate this work to her mother, who encouraged her to pursue the doctorate program. 


\section{ACKNOWLEDGMENTS}

The author wishes to acknowledge the faculty members in the Instructional Design and Technology Program who helped and encouraged her. To her advisor, Dr. Ahern, who helped her through the decision of research topic. To Dr. Hursh, who encouraged her to think critically about her research topic, and always had very thoughtful questions to ask.

To Dr. Shambaugh, who taught her to create instructional design in a systemic fashion.

To Dr. Kale, who offered his international opinion on international education. Finally, Dr. Zwickel, who provided a wonderful outside view on the topic. 


\section{TABLE OF CONTENTS}

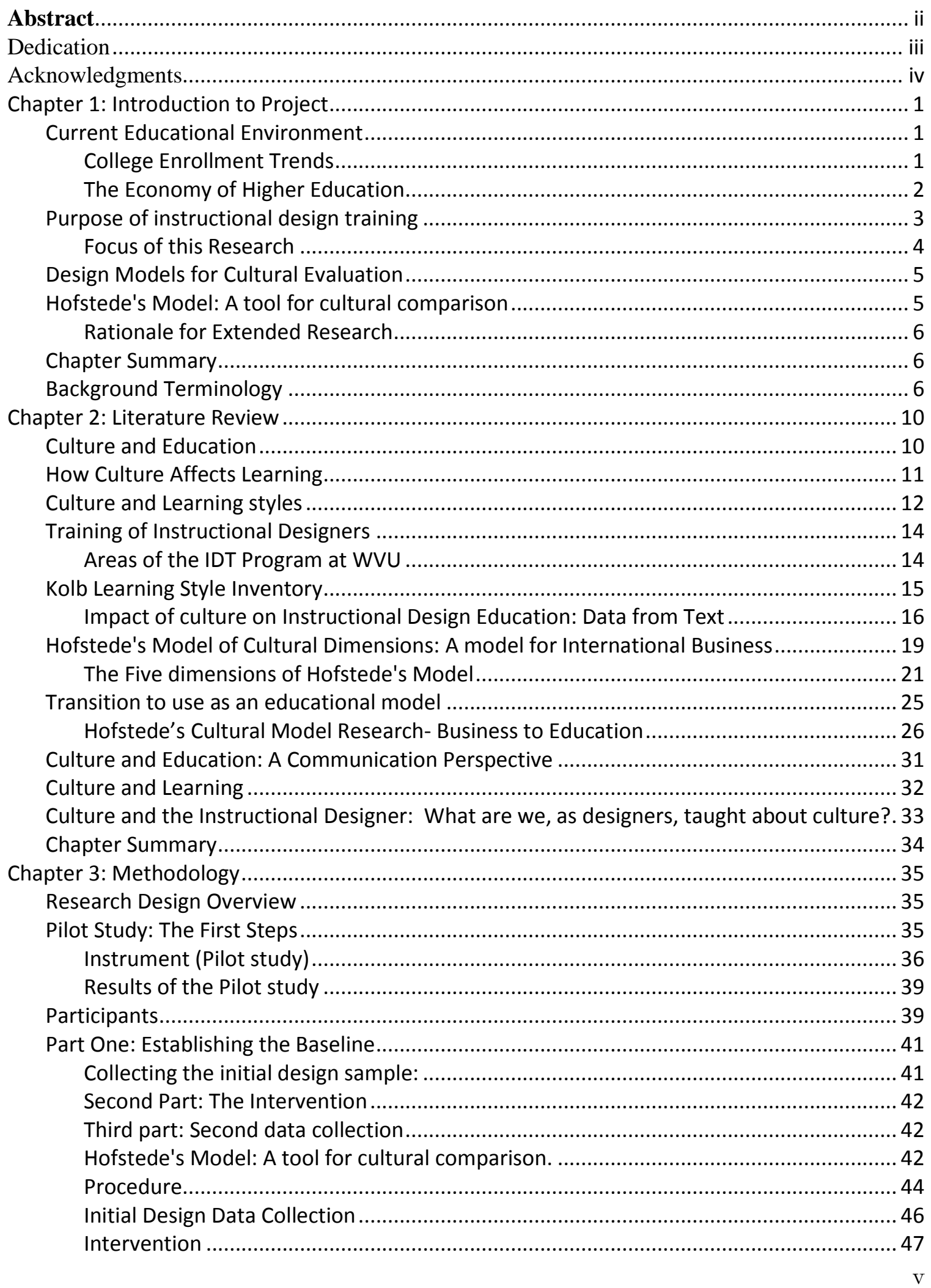




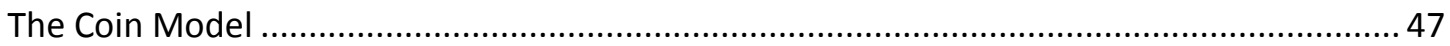

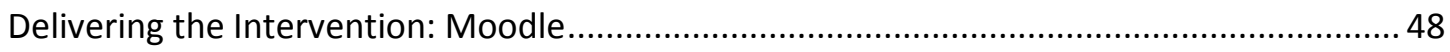

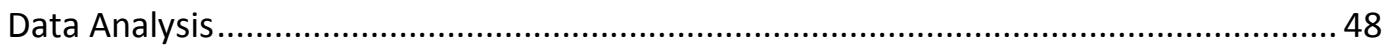

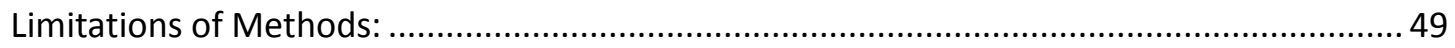

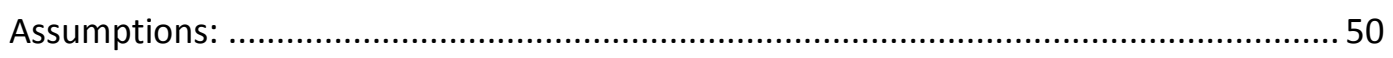

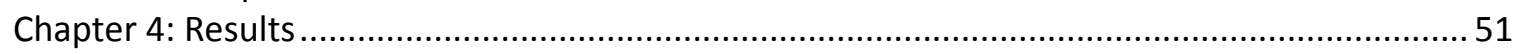

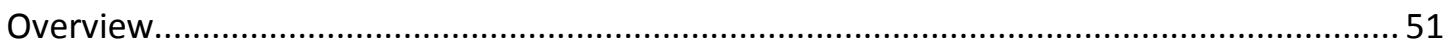

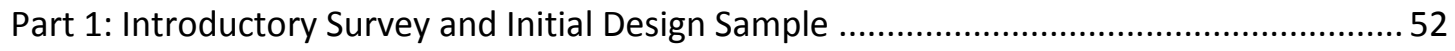

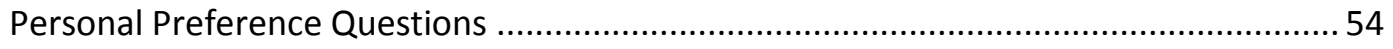

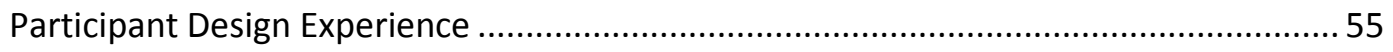

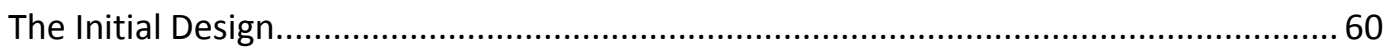

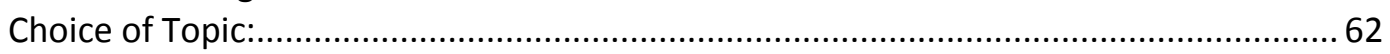

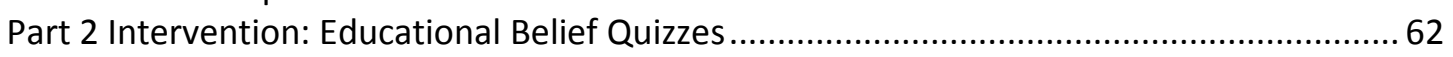

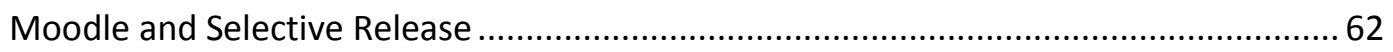

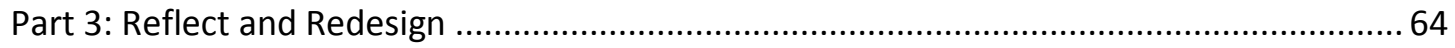

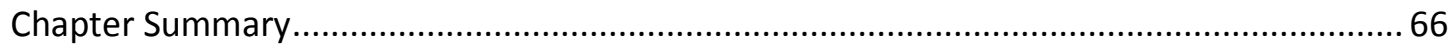

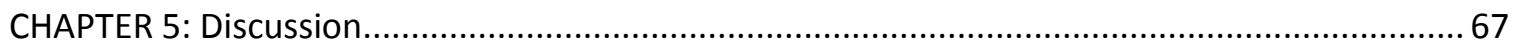

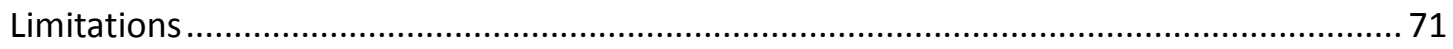

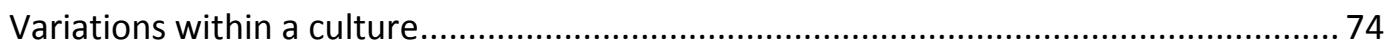

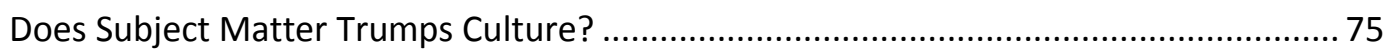

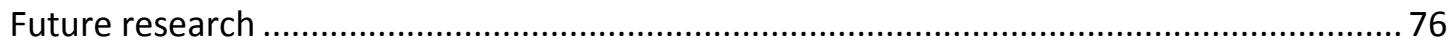

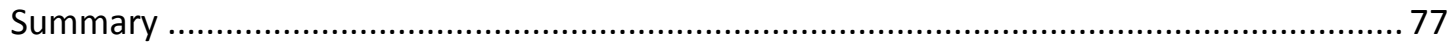

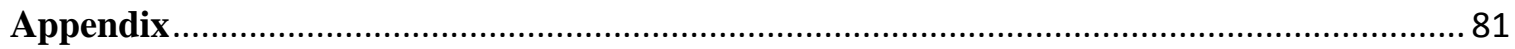




\section{LIST OF TABLES}

Table 1 Learning Preferences (Communication between Cultures.................................................... 13

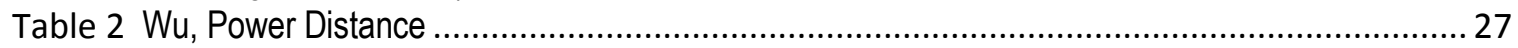

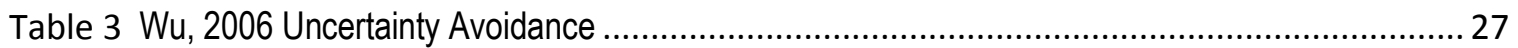

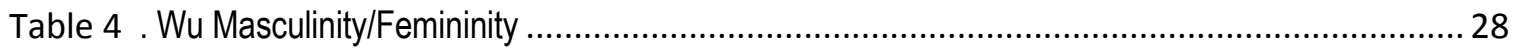

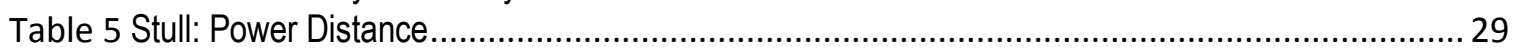

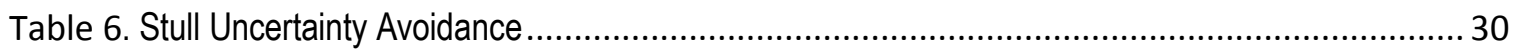

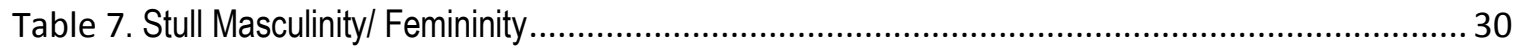

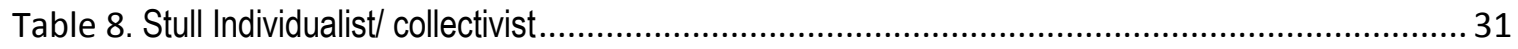

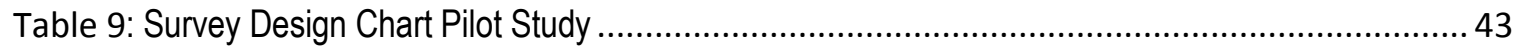

Table 10 Overview of Hofstede's Model of Cultural Dimensions ............................................................ 45

Table 11: Established Ranking of participant culture by Hofstede's Model ........................................... 45

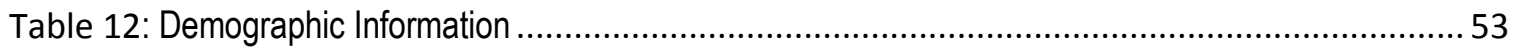

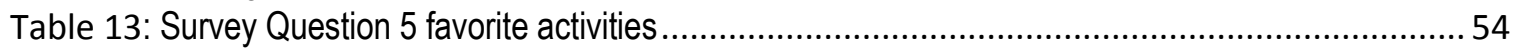

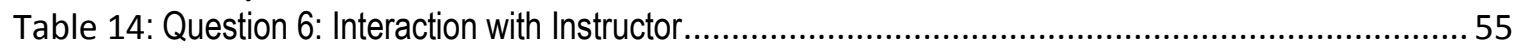

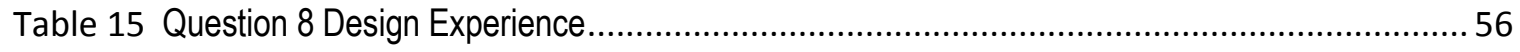

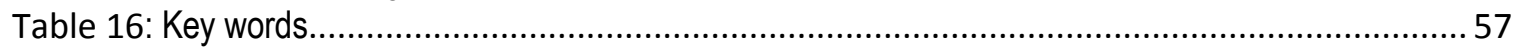

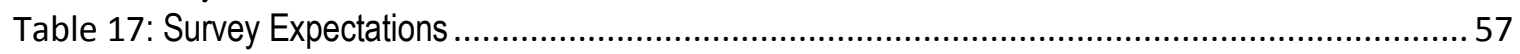

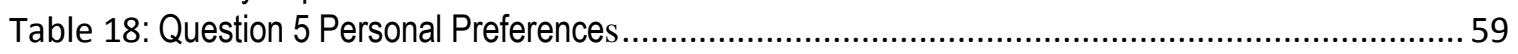

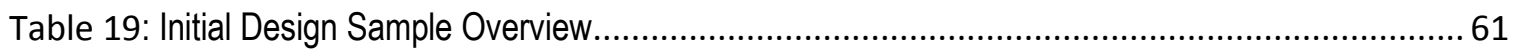

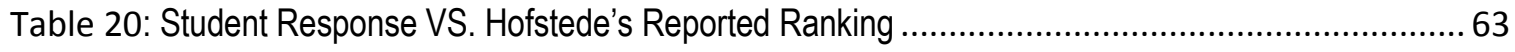

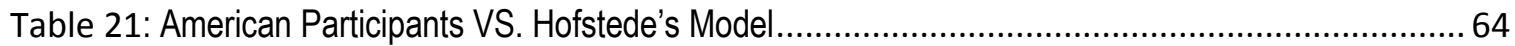

Table 22: Instructional Design Sample-initial and Revised Submissions ............................................. 65 


\section{CHAPTER 1: INTRODUCTION TOPROJECT}

\section{Current Educational Environment}

One aspect of course development that is taught in curriculum development and instructional design is the importance of understanding the learner. However, the effect of the background culture of the instructional designer on course development has generated little research. Changes in education systems worldwide have made this a more significant concern. At the college level, increasingly more universities teach courses to a diverse student body. This has had an effect on the economy of higher education. Background culture also has an effect on the training of instructional designers. Adapting the training to reflect an understanding of background culture could influence how instructional designers develop instruction.

\section{College Enrollment Trends}

Today colleges in America form a multi-cultural environment. There are Intensive English Programs for students whose primary purpose is to study English. This may be as part of a study abroad at their university, or as a pathway towards undergraduate and graduate education. Entrance policies, for international students, involve a language proficiency test, TOEIC/TOFL to assure the student has the minimum linguistic ability to engage in classroom activities. Cultural elements are often left out of the orientation process. Students understand that they will have culture shock, but not how it will relate to the classroom experience. The growth of higher education programs with a multicultural student base has created classrooms where instructors will be interacting with students from other cultures. 


\section{The Economy of Higher Education}

Developing instructional design can create a learning environment that crosses cultural boundaries, facilitates learning, which in turn will benefit the American economy. The American education at the post-secondary level relies on drawing more international students into the classroom. International students contribute approximately $\$ 13.5$ billion dollars to the U.S. economy, through their expenditure on tuition and living expenses. Department of Commerce data describe U.S higher education as the country's fifth largest service sector export, as these students bring money into the national economy and provide revenue to their host states for living expenses, including room/board, books and supplies, transportation, health insurance, support for accompanying family members, and other miscellaneous items. (Hefling, 2012)

In 2009 the Chronicle of Higher Education reported that the number of foreign students in the U.S. had hit a new high. Reasons for this include the fact that the U.S. still remains a top destination for foreign students. Another reason being that key source countries, like China and India, cannot meet the demand for higher education. (Fischer, 2009)

These learners take courses created by American designers, and through word of mouth advertise their experience to friends and family. Ensuring that the educational standards meet the educational and cultural expectations of the students is crucial.

It is important to understand how the designers can work as part of a diverse design team. The education of the instructional designer involves training in many areas. In the Instructional Design and Technology program at West Virginia University, the core classes involve developing knowledge in three disciplines: Instructional Design, 
Educational Psychology, and Research Methodology. This should prepare the instructional designer to create, evaluate, and implement curriculum in various institutions. Cultural training in this program is currently taught implicitly.

Globalization and the university education system not only effect the U.S., but many countries around the world. This can be illustrated by the article Japan Mulls Shifting Its Academic Year to get in Step with the West (McNeill, 2011), which discussed proposed changes to the Japanese higher education system. Traditionally, Japan's education system begins in April, instead of the August start that most American institutions are on. This offset has a huge impact on students because they must consider the time lapse between these two systems when deciding if they want to study abroad. There is legislation in the Japanese Ministry of Education to adapt the higher education timetable to the Western timetable, which would increase the appeal of study abroad.

\section{Purpose of instructional design training}

Programs training instructional designers need to understand if current methods are effective. The WVU College of Education and Human Services homepage states the purpose of the Instructional Design and Technology Doctoral Program is described as follows "The Ed.D. Program is designed to allow a student to immediately apply knowledge and skills to pragmatic needs in education. Knowledge and skill-building are designed into the courses and are developed over the length of the program, and specifically address three areas of concern in educational settings, including interconnectivity, instructional design, software and multimedia design and deployment. Research is framed around the pragmatic needs of students, programs, and institutions." (WVU IDT) 
At Texas A\&M the Instructional Design program's purpose is similar in nature "The Master of Science in Instructional Technology program is designed for individuals seeking to be practitioners in the field of instructional technology. It prepares graduates for a variety of professional positions in diverse contexts, such as instructional designers, trainers, e-learning specialists, technology integration specialists, human performance technologists, and human resource development personnel.

Instructional designers are asked to create curriculum for use in many learning environments. Designers are not simply individuals acting alone, but more often than not as a member of a design team. Often the members of this team have their own ideas on handling instructions. Working with the other members of the team they create learning solutions. They are often required to assess how effective the instruction is through the use of assessment tools. Further, the designers themselves are embedded within a bounded cultural context that influences design decisions both implicit and explicit. This cultural-bounding can impact the design of instruction.

\section{Focus of this Research}

The purpose of this dissertation is to explore the current training of Instructional Designers, and the influence of the designers' culture on the instructional design process. The topic came about through the researcher's interest in culture and instructional design. Having taught abroad for several years informal observations established that the designer would occasionally made design decisions that were not understood by the students. The question became "Could the designer be made aware of this?". Because an instructional designer makes many decisions in the design process it would be important to understand their own background. By placing the focus of the research on the 
Instructional Designer it will also help the programs offering training in Instructional Design to comprehend the effectiveness of their programs and know if the addition of a cultural element would impact the design.

\section{Design Models for Cultural Evaluation}

One factor that needed to be considered when developing this project was how to evaluate instructional designs from different cultures. Instructional designers need a way to compare designs and understand the cultural values. These are the cultures that they are designing for, and have an understanding of their own cultural background. The model was that it should be able to compare multiple cultures. While searching for established models for comparison Hofstede's Model of Cultural Dimensions was found. It was used for evaluating communication in a business setting, but it had possibilities in the classroom.

\section{Hofstede's Model: A tool for cultural comparison}

As stated in the introduction of this paper, one of the objectives of this project was to find a tool to use to evaluate the decisions that instructional designers make. Even though Hofstede's Model of Cultural Dimensions data was developed for international business communication translating this tool for use in the classroom did not seem to be that difficult (Hofstede, 1984). The same cultural dimensions, that Hofstede uses to compare cultures in business, seem to be an underlying part of an individual's personal background. Table 1 below shows the implications and expectations for the survey questions asked can be related to Hofstede's model. 


\section{Rationale for Extended Research}

Using the data from the pilot study, as well as current trends in education, it was proposed that an expanded project be undertaken. This research is important because of the changing educational system at all levels. At the public school level immigration is creating a diverse student base. At the tertiary level there is an increase in international students. Technology has also created an impact on instructional design process by bringing students from around the world together. Creating an environment where educational culture is explicitly understood could establish more effective interventions.

\section{Chapter Summary}

The changing educational environment is important in understanding the impact of background culture on instructional design. Through the use of tools, such as Hofstede's Model of Cultural Dimensions, Instructional Designers will be able to evaluate their designs more effectively. Instructional designers need to have a way of expressing their personal preferences without feeling that one method is "right" or "wrong". Allowing Instructional Designers to talk to other Instructional Designers, or teachers, without threatening could create a better environment when working in a team.

\section{Background Terminology}

During this research certain terms will be used to discuss education and training styles. Below are some of the key terms, and how they will be defined within this project.

\section{Cultural-boundedness}

The term cultural-boundedness was coined to refer to the implicit impact that a culture has on a person. It is part of human nature to view things in relationship towards 
past cultural experiences. Previously terms used to describe the influence that culture has on an individual may have negative connotations. Terms such as cultural bias have been used, but have a negative implication.

\section{Explicit Training}

Explicit training, for purposes of this research, will be defined as items that are purposefully taught. References to this term will be used as part of cultural and educational practices. To understand how culture plays a part in the educational program of an instructional designer it is necessary to examine what is taught explicitly and implicitly.

\section{Implicit Training}

Implicit training will also be used within the scope of culture and education. As opposed to explicit training, implicit training occurs without conscious instructional intent by the instructor. Correct, or expected, behavior is taught as part of a person's inculturalization. It is often more difficult to identify implicit training that happens in the classroom. In the context of this study it is used to understand why the teacher and instructional designer make some of the decisions they make when creating the classroom environment.

\section{Instructional Designer}

For purposes of this research the Instructional Designer is the person(s) responsible for the development of the course. It can be the subject matter expert, or instructor, who has a clear understanding of what the students need to learn. 


\section{Hofstede's Model of Cultural Dimensions}

When discussing models for comparing culture Hofstede's Model of Cultural Dimensions will be used. This model was created by Geert Hofstede to compare cultures in a business setting. This will be used as a tool to evaluate educational beliefs, and expectations of interaction in the classroom.

\section{Confucian Method}

The Confucian method of instruction evolved from the philosophy of Confucius. This will be used as the background to educational philosophy in many Asian countries. In comparison to Western beliefs on education Confucius valued memorization. Other Confucian values, such as the teacher/student relationship, will be discussed as background information on the development of education.

"Contrary to the Western method or approach to reality, the Eastern philosophers take the totally different Way or philosophical method to reality. The process of the procedure to approach reality seems to be exactly the opposite. Namely, take for example, the teacher does not provide his/her disciple with the abstract definition. On the contrary, the quasi-abstract concept is illustrated by a concrete, particular situation. This is one of the difficulties that those who are trained in the Western way or method to understand the Chinese classical philosophy. The teacher does not help the student step by step what is to be learned, nor "explanation." When we were children, we sat properly in front of our father and he aloud reads one phrase after another from Confucius' Analects. We recites it one by one, and memorized it. Of course, being 7-10 years old, we did not understand what it meant. And many hear passed and often they are forgotten. 
However, suddenly, our eyes are opened to those phrases and we understand them! This is the method of the East. "Methods of Philosophy lecture" 2: retrieved from online lecture notes August 4, 2013 from California State University (N.D.)

\section{Socratic Method}

In the West the traditional educational philosophy has been based off of the teachings of Socrates. This term will be used as part of the educational philosophy and teaching styles. "The use of questions, as employed by Socrates, to develop a latent idea, as in the mind of a pupil, or to elicit admissions, as from an opponent, tending to establish a proposition." Socratic Method (N.D)

This cultural bounding becomes part of our deep, or low culture, and as adults we do not normally think about it or question it. For example in the Asian educational system the instructor is the source of knowledge, which largely follows the Confucian

model. In the Confucian model, the students are expected to listen and then recite back to the instructor what they were told. They do not directly question the instructor in class, but normally wait until after class to ask any questions that they might have. In contrast to the Western view of instruction where students are challenged to question what they hear which aligns philosophically to the Socratic Model. 


\section{CHA P TER 2: LIT TERATURE REVIEW}

The cornerstone of this research project involves culture and its effect on education, the way in which instructional designers are currently taught, as well as a tool to evaluate and discuss cultural expectations in an educational environment. As part of the research for this project these topics were explored to develop an understanding of current research and beliefs in these areas. First, teachers and designers make conscious and unconscious decisions based on their native culture. Further, education is a crucial part of the cultural development of an individual. As educated adults students of instructional design come into the classroom with this cultural background. Instructional designers are taught to make some decisions explicitly to ensure good design such as knowing the student and how to develop instruction revolving around student needs.

\section{Culture and Education}

One question that needed to be answered concerned how culture effected education. To establish how culture affects education, we must have an understanding of what culture is. While there are different definitions of culture, based on the area of interest, most definitions of culture include the concept of shared attitudes and beliefs within a group of people. These commonalities allow us to form a definition for purposes of this research. The University of Minnesota's Center for Advanced Research on Language Acquisition (2011) gives several definitions from an International Studies viewpoint. All definitions include the concept of collective beliefs as part of what creates a culture. (CARLA, n.d.) 
When most people are asked to define culture it normally, includes ideas such as the food, language, and arts of a specific group of people. For purposes of this study this definition will be referred to as "High Culture". Other aspects of culture which does not include food or language, such as formal meeting or classroom etiquette would be considered "Low Culture". This directly relates to the implicit and explicit training.

High culture is normally taught explicitly to members of the group as part of their cultural heritage. Another way of looking at this would be things that the members of that culture would put in a time capsule for others to find. In contrast Low Culture, is the everyday activities of a people. Low culture encompasses all the underlying values of a culture such as defining correct conduct or appropriate gender role. Typically the education system of a country is considered a part of its low culture for it establishes what is taught, how members of the society are taught as well as which members are educated.

\section{How Culture Affects Learning}

Samovar (2008), in Communication Between Cultures gives examples of how the education system of a country provides information on the culture. What cultures choose to teach gives us information on the belief system of that culture. All cultures tend to include their history, their major religion, and basic skills (reading, writing, mathematics) in their curriculum. When looking at the education system of a country it is possible to get a glimpse of the underlying values of that culture. In China and Japan part of these core values include cooperation and interdependence. What is taught to students can give researchers an idea of expectations for development at various stages of development. In 
Japan higher level math skills are taught at lower grade levels. (Savomar, 2008 pp256283)

Culture impacts not only what is being taught, but decisions on who is being taught. In some cultures, education is the prerogative of the rich. Other cultures may focus on academically gifted students. Gender may play a role in the educational opportunities in other cultures, such as the Middle East where female and male students are educated separately.

Online classes are increasing every year, and that means that instructional designers have to change the design process in order to take into account this new delivery system. Universities are designing integrated study abroad programs that impact the design of the courses because it could include students at universities in two countries.

\section{Culture and Learning styles}

Culture can also impact the preferred learning style that a group of students have. Savemore (2008) discusses culture and preferred learning styles in his textbook. The instructional designer may not be explicitly aware of how these preferences affect their design, but implicitly they may follow these preferences when creating their ideal classroom experience. These values can be linked with Hofstede's Model of Cultural Dimensions. Notes in red represent the ideas on how this could relate to Hofstede's Model. 
Table 1 Learning Preferences (Communication between Cultures

\begin{tabular}{|c|c|c|c|}
\hline & Linear-Active & Multi-Active & Reactive \\
\hline \multirow[t]{3}{*}{ Values } & $\begin{array}{l}\text { Value facts and figure } \\
\text { Associated with masculine } \\
\text { qualities/style } \\
\text { Could be shown by the } \\
\text { types of } \\
\text { assignments/questions } \\
\text { asked. }\end{array}$ & $\begin{array}{l}\text { Value emotions, close } \\
\text { relationships and feelings } \\
\text { Associated with Feminine } \\
\text { qualities/style }\end{array}$ & $\begin{array}{l}\text { Value subtle } \\
\text { communication; } \\
\text { listen first, then } \\
\text { respond } \\
\text { *Japan tends to } \\
\text { require the } \\
\text { memorization of } \\
\text { facts, could be } \\
\text { influenced by class } \\
\text { size* }\end{array}$ \\
\hline & $\begin{array}{l}\text { Respect highly organized } \\
\text { planners } \\
\text { Could be shown by the } \\
\text { planning/directions }\end{array}$ & Act out more impulsively & $\begin{array}{l}\text { Honor, harmony, } \\
\text { humility, and } \\
\text { agreement } \\
\text { These are } \\
\text { traditionally very } \\
\text { Japanese } \\
\text { qualities. }\end{array}$ \\
\hline & $\begin{array}{l}\text { Think linearly } \\
\text { How are the lessons } \\
\text { approached? }\end{array}$ & $\begin{array}{l}\text { Prefer face to face } \\
\text { interaction }\end{array}$ & \\
\hline \multirow[t]{3}{*}{$\begin{array}{l}\text { Communication } \\
\text { style }\end{array}$} & $\begin{array}{l}\text { Use a straightforward, } \\
\text { direct communication } \\
\text { style } \\
{ }^{*} \text { Associated with } \\
\text { Masculine qualities* }\end{array}$ & $\begin{array}{l}\text { Use direct and animated } \\
\text { communication styles }\end{array}$ & $\begin{array}{l}\text { Use indirect } \\
\text { communication } \\
\text { style } \\
\text { *Associated with } \\
\text { more feminine } \\
\text { qualities* }\end{array}$ \\
\hline & $\begin{array}{l}\text { Take task-oriented } \\
\text { approaches } \\
\text { *Associated with } \\
\text { Masculine qualities* }\end{array}$ & $\begin{array}{l}\text { Feel uncomfortable with } \\
\text { silence }\end{array}$ & $\begin{array}{l}\text { Tolerate silence } \\
\text { and find it } \\
\text { meaningful } \\
\text { Japan also } \\
\text { tolerates silence. }\end{array}$ \\
\hline & $\begin{array}{l}\text { Prefer rationalism and } \\
\text { science over religion }\end{array}$ & & \\
\hline $\begin{array}{l}\text { Typical cultures } \\
\text { where these } \\
\text { learning styles are } \\
\text { preferred. Seems } \\
\text { to follow the chart } \\
\text { in "Does culture } \\
\text { effect learning } \\
\text { style" }\end{array}$ & $\begin{array}{l}\text { White American, Western } \\
\text { Europeans }\end{array}$ & $\begin{array}{l}\text { African Americans, } \\
\text { Arabs, Latino }\end{array}$ & $\begin{array}{l}\text { Asian Americans, } \\
\text { Pacific Islanders, } \\
\text { Native Americans }\end{array}$ \\
\hline
\end{tabular}

Cooperation versus competition: Hofstede talks about individualism, while communication texts talk about the variation between cooperation versus competition in a culture. In a Spanish classroom students are encouraged to cooperate. Students are 
rewarded when the group as a whole succeeds. The Spanish classroom is very structured, reflecting the high Uncertainty Avoidance ranking of 86 (Samovar 2008 p. 262).

\section{Training of Instructional Designers}

Having established impact of culture on education practice the next step was having an understanding of how instructional designers are currently trained. The instructors, teaching instructional design and curriculum development, will also reflect their cultural-boundedness in their teaching style and decisions. This research will include the structure of the training, and how culture is included in the design.

Instructional designers are trained by an explicit step-by-step process stemming from what theory considers "best practice". Items taught explicitly include learning goals, material, student demographics, i.e., age or educational level. Furthermore, training in instructional design involves a deep understanding of the learning theories. Theories are an important part of the Instructional Design process. According to Shiffman (1994) "A solid foundation in learning theory is an essential element in the preparation of ISD professionals because it permeates all dimensions of ISD” (Shiffman, 1994, p. 139).

\section{Areas of the IDT Program at WVU}

Incorporated into the 72 hours necessary for degree completion students must take classes in three areas: a common core area, a research area, and within three specialization areas. The common core area is constant for all graduate students in the college of Human Resources and Education. It includes psychological foundations of learning and principles of instruction. This assures that the designer will have a working knowledge of modern theories of how the human mind works. The second core area, the 
research core, gives students a background in the accepted practices of doing research to stay current in the field. These two core areas have been selected as part of the explicit training of the Instructional Designer. The instructional designer also has the option of choosing classes within selected "specialization" areas.

In order to design instruction an Instructional Designer must also understand how students learn. Educational Psychology courses, which teach this, are also part of the instructional design program. The dominant learning theory in the United States is Cognitivism, which has several implications for the instructional designer. If there is a belief that people construct an understanding of the world around them, then the designer will provide opportunities for students to experiment and test their understanding of what they are learning.

Learning Theories and the Practices of Instructional Design describes some of the different methods of instruction. Cognitivism, which is task oriented, orients the design choices towards the accomplishment of a task.

"When designing from a behaviorist/cognitivist stance, the designer analyzes the situation and sets a goal. Individual tasks are broken down and learning objectives are developed. Evaluation consists of determining whether the criteria for the objectives has been met”. (Schuman, 1996)

\section{Kolb Learning Style Inventory}

Instructional designers learn to formulate their learning objectives based on these cultural values. In the United States educators place a value is placed on critical thinking skills. This is one of the major objectives that is cited in the syllabuses of many in a MidAtlantic University courses. Other cultures may place more value on being able to recall 
pieces of information. What is not an integral part of the educational process is developing a self-awareness of culture and how it can impact the quality of the design.

\section{Impact of culture on Instructional Design Education: Data from Text}

Establishing that culture affects decision making at an implicit level the next step was to relate this to the current education of instructional designers. The current design process involves training people to create instruction in a systematic way. To achieve this outcome the design process in most textbooks provides explicit steps for creating effective instruction. For example Morrison (2004) in his textbook Designing Effective Instruction, discusses the steps necessary to create good instruction. He has the designer consider the learner as well as the importance of looking at the learner characteristics when designing instruction. Identifying additional characteristics of the learner, as well as an understanding of different learning styles are given explicit instructional time in the text. Notice the focus is on the learner and not on the designer. This is typical of most instructional design textbooks. What is left out is an understanding of the influence the designer's culture might have on the design process.

Mastering the Possibilities (Shambaugh, 1997 p. 102) discusses cognitive learning strategies as part of the instructional design process. Shambaugh has the designer consider the learner as well as the importance of looking at the learner characteristics when designing instruction. Identifying additional characteristics of the learner, as well as an understanding of different learning styles are given explicit instructional time in the text. Notice the focus is on the learner and not on the designer, which is typical for most instructional design textbooks. These textbooks emphasize the perspective that gaining an understanding of the influence their culture may have on the design process. 
While instructional designers need to be aware of these different learning styles and how to deal with them when they come together in a classroom they also need to be able to understand their own perception on design which is not typically taught in instructional design textbooks. Educational researchers need to be aware of their assumptions and how this can create research bias. Likewise Instructional Designers could benefit from being aware of their own cultural-boundedness. Just as research bias can lead to inaccurate reporting of information and can cause a witness to ignore, distort, or overemphasize incidents (McMillan, 1978 p. 478) designer bias may lead to inappropriate or ineffective instruction.

To establish where the explicit design decisions come from, it is important to look at the textbooks used to teach instructional designers. These textbooks used do not normally include a discussion on implicit design decisions that designers make. Talking with American designers and instructors it is understood that Japanese students are quiet in the classroom, and do not offer information in class willingly. By understanding the reasoning behind this behavior would the designer make different decisions?

To understand the importance of designing for a culturally diverse classroom it is necessary to understand the changes that have happened over the past ten years. In the US the diversity of students is growing. At the public school level the number of students who speak a language other than English at home is growing, such as Hispanic students in the southwest or Chinese on the West Coast. While it may have been previously possible to develop material for a homogeneous group of learners, today's instructional designers require a very different skill-set on the design process. One of the learning 
goals shared by the students and administrators is having the skills necessary to interact in a society where interaction between cultures happens on a continuous basis.

However, other design decisions are more implicit and stem from deep-rooted cultural expectations of past educational experiences. This training happens slowly over the course of the designer's life. Most people are unaware of this training. Asking a person to explain what type of education system they grew up with might create some confusion even if they had training in education or instructional design. The reason for this is that, as a part of the system, they do not think about everything that happens within that system. They will not be aware of other educational systems. The type of interaction the designer expects, the tools they include, and the learning style they prefer can be traced back to their past educational experiences. Schools represent a context in which both the socialization and learning process occur (Samovar, 2008 p. 236). For example, the expectations on the type of interaction students should engage in are often culturally bounded and are typically implicit in nature.

This type of training is important to understand because Instructional designers also make decisions based on personal preferences. Consider the old adage "Teach as you were taught" rings true. If the designer has a method of learning that they feel works best for them then they will probably incorporate that into the design plan and not consider other learning styles. For example, American designers typically choose to implement designs that consider student-to-teacher and teacher-to-student interaction of high importance. They expect students to speak out in class; to question the content, illustrating a lower power distance ranking. However, designers from other cultures can find this design choice at odds with a more typical teacher-to-student interaction. 
Consider the Japanese classroom, where oral communication is not emphasized (Samovar, p. 261). The cultural differences between Eastern, and Western-educational technique exerts an implicit influence on design practice realized in each the educational learning style.

One of the problems in Instructional Design is that designers do not consider as much the "social" as we do the "cognitive" factors, but we know the cognitive is driven by the social. It is important to look at the notion of epistemology - and its culturalboundedness in relation to Instructional Design.

Technology is also a factor in the new classroom dynamics (Salomon, 1991). Around the world students and educators are making more use of technology in education in the form of online or blended learning environments. Universities are asking instructors to incorporate technology into their courses that may then be available to students from round the world. This has created an environment where culturally diverse student populations come together.

\section{Hofstede's Model of Cultural Dimensions: A model for International Business}

To evaluate the response of the instructional designer and establish how their background culture affects their design it was important to choose a model of cultural comparison. In this study we chose to use Hofstede. Hofstede was a Dutch Social Scientist who was interested in international business communication. The model that he developed has three levels. It claims that we are born into certain cultural traits. There are standards of behavior for each culture. Additionally, there are individual cultural traits that affect a person's reaction to a situation. He established five dimensions of culture 
and then rated 81 nations on those dimensions, but added a sixth later on. Hofstede's definition of culture includes the idea of collective programming to distinguish one group from another. "Culture is the collective programming of the mind which distinguishes the members of one category of people from another." (Hofstede, 1984, p. 51)

Hofstede's model was chosen because it was well established. During the sixties and seventies he collected data when working for IBM. These five dimensions were originally intended for studying the intercultural interactions in a business environment. Upon evaluating them however these dimensions could also be used to understand the cultural differences present in the classroom, because the same cultural understanding of how to behave in a social situation has partially learned in school.

He conducted a survey on members of subsidiaries of IBM and used that as a national norm. (Dr. Geert Hofstede ${ }^{\mathrm{TM}}$ Cultural Dimensions, n,d.)

He developed a mathematical formula to rank countries based on the response to the answers to the survey questions. An overview of this formula is provided below:

The mathematical formula he used to establish the cultural rankings was:

Organizational Culture $=$ OrC

Occupational Culture $=\mathrm{OcC}$

National Culture $=\mathrm{NC}$

$\mathrm{NC} 1=\mathrm{NC} 2=$ Differences between the cultures

When looking for a model that would provide the ability to compare one culture to another. Hofstede's model of cultural dimensions was developed for international business, but has also been used in a classroom setting. One of the questions that came about in formulating this research project was what tool to use to evaluate culture. The purpose of this research was to be able to have a better understanding of how background 
culture, in this case that of the designer, influences the design process, and to have a measurable model.

\section{The Five dimensions of Hofstede's Model}

Research on the influence of culture in the classroom, using Hofstede's Model as the tool to compare findings, has been done in several cultures. To look at how each dimension might be reflected in the classroom a short analysis was done.

The first of the five dimensions Hofstede compares in the Power Index. By looking at each dimension, and how it is used in business, it is possible to establish how it can be translated to the classroom experience.

1. Power Distance: PDI (Power Distance Index) is the amount of tolerance in power distribution within a society. To what degree do members of that culture accept that power may be distributed unevenly? High PDI cultures may tolerate a degree of dictatorship from the leaders, or look up at the teachers as gurus and respect them accordingly. Low PDI cultures on the other hand, see very little gap between the higher-ups and subordinates and expect more equality. (The Hofstede Center, N.D.)

In a business situation this may translate to how much power the employees have. In the classroom it could be looked at as how much power the teacher has. Japan and the US are fairly close on this scale, so we would expect to find similar expectations.

How would we take this into account given the code of conduct in the classroom? In the researches experience in Japan, Japanese students call their instructor by their family name. They also use the term "Sensei" which means teacher and has an undertone of respect in that culture. The subject of culture and learning style was addressed by Kolb 
in "Are there cultural differences in learning style?" This article discussed how cultural dimensions impacted preferred learning styles. "Students from high power distance cultures often seem uncomfortable with professors who want to be called by their first name and Asian students appear quiet and reflective in the extroverted, high participation American classroom" (Simy, Kolb, 2008). They are more likely to expect the instructor to be correct and not challenge them during class discussions. In a business situation, similar expectations establish the relationship between the boss and employee. Expectations that we can take charge as we grow up. The ability to challenge a grade, or contradict the instructor are culturally bound. Interacting with the instructor is also bound by cultural rules. According to Signorini (2009) nations with a Large Power Distance rating are more likely to perceive the instructor as the "Guru" whose ideas are not to be questioned. It is the instructor who drives communication and forms the rules. An instructional designer from this cultural background will use these educational beliefs in the development of the course.

\section{Individualism vs. Collectivism: Individualism pertains to cultures with loose} ties. Members are expected to look after themselves and their immediate kin. Collectivism believes in strong social ties where the key is trust and loyalty in relationships with other members, and beyond the immediate kin. IDV (Individualism Index) is used to measure this dimension. To show how strong this concept can be one only has to look at the 2011 earthquake in Japan. Even though supplies were short there was no news of riots breaking out. Orderly evacuations were conducted for the good of the group. This is taught to through implicit interaction with members in the group. 
In the classroom this aspect of culture will be addressed by expectations concerning assignments. All students are presented with the same information regardless of ability level. From the researcher's personal experience: In the Japanese culture the group is held responsible for the success of the members. They must function as a group. Junior high school students are grouped in "Gumi" or homerooms. They study throughout the day with the same students, thus forming a group bond. During the process of preparing for new seventh grade students the instructors have a meeting where they create these "gumi". Having gained permission to sit in on this meeting it was found that the school faculty took great care in forming these groups considering academic ability, sports aptitude, leadership skills, and other factors. The purpose was to form, in this case three, equal groups. This is very different from the American school system where the individual student takes precedence and students are placed according to similar abilities. Advanced Placement courses are available for students who show academic talent in an area, while remedial classes available for those whose performance level is lower.

3. Masculinity vs. Femininity: This refers to gender roles within a culture. A culture is masculine when roles are distinctive and such qualities as assertiveness, toughness, and materialism are the dominant qualities. As opposed to the feminine cultures where the roles are overlapping, and qualities such as modesty, softness and family orientation are dominant. MAS (Masculinity Index) is used to measure these gender roles in different cultures. 
4. Uncertainty Avoidance: Different cultures react with different levels of anxiety to the unknown. Strong UAI (Uncertainty Avoidance Index) cultures are suspicious of change and consider 'different' as dangerous. Low UAI cultures are more open to new ideas and 'different' raises curiosity rather than alarm.

When designing classes this is important to look at for the following reasons. The style of questions that an instructor asks will be different depending on this ranking. An American instructor, who normally has a low uncertainty avoidance ranking, might present a question that would require a student to 'guess' when answering a question. In high uncertainty avoidance populations such 'guessing' can create stress for the student. This suspicion of change is also important when the instructional designer discusses new technology and techniques with the subject matter expert. It may provide clues when looking at how an academic program implements 'new' ideas.

5. Short-term vs. Long-term Orientation: This dimension weighs the influence of tradition against progress. In some Asian cultures, government and businesses are modeled based on family values and hierarchies. Also, other elements such as religion may be the dictating factors. A short-term orientated culture is one that has strong traditional bonds, but values are not always measured logically and progress can be comprised for the sake of status and immediate results. In contrast, a long-term orientation sets a practical limit, while respecting traditional and social obligations. This dimension is measured by LTO (Long-Term Orientation) index. 
This dimension was added by Hofstede in response to a statement that his design was oriented towards the west. We will not be using this dimension in our research, because it has not been as thoroughly documented, and not all the countries included in the survey were included.

Hofstede's cultural model is not the only one, some of the others that followed are: 4-dimensional model of Hall and Hall (1990), 14-dimensional model of Reeves (1992), 7-dimensional model of Trompenaars (1993), 19-dimensional model of Collis, Vingerhoets, and Moonen (1997), and 9-dimensional model of Khaslavsky (1998). These models or a combination of them have been used in different applications and all are excellent resources for studying cultures and identifying their specific characteristics. Hofstede explains that "different authors' minds produce different sets of dimensions", and in reality cultures or dimensions do not exist. "Dimensions, and culture in general, are 'constructs', products of our minds that help us to simplify the overwhelming complexity of the real world, so as to understand and predict it. They are useful as long as they do this, and redundant when they don't. And because the real world is so complex, there is not just one way to simplify it" (Hofstede, 2005).

\section{Transition to use as an educational model}

The next phase of the literature review was to explore ways in which Hofstede's Model of Cultural Dimensions was being used in an educational context. It was also important to find previously established questions that could be used in the Educational Beliefs Quizzes. Other articles using Hofstede Model in the multi-culture classroom views educational beliefs from the perspective of student behavior in the classroom. To find out how Hofstede's model is being used in the classroom. In 2006, Wu used 
Hofstede's Model of Cultural Dimensions in a survey of university administration in the US and Taiwan. Site articles and give detail on how they used the model and findings.

\section{Hofstede's Cultural Model Research- Business to Education}

Hofstede developed his model to be used in a business environment, so the next step was to locate any previous research on using this model in the classroom. Attempts to use Hofstede's Model of Cultural dimensions in the classroom can be found in research conducted by $\mathrm{Wu}$ (2006). One of the core research questions he had was to determine if the cultural ranking Hofstede established reflected the current culture of countries. Another concept he was interested in was the validity of this business model to reflect the educational cultural standard. This is very relevant to this project for several reasons.

First, it will establish if the scores being used as the baseline for the research are accurate. Second, it will provide some background information on how rapidly globalization influences a culture. Third, the survey questions used as part of this research influenced the questions developed as part of the intervention for this project. To do this he looked at the administration of two universities, one in America and one in Taiwan. The questionnaires that he developed involved administration at the university level.

Table two through four shows some of the questions that Wu uses to establish Hofstede's Cultural Dimensions. These can then be tracked to the underlying concept that is important, and then translated to the classroom experience. The questions shown tend to focus on the high side of Hofstede's Model allowing the participant to agree or disagree. 
Table 2 Wu, Power Distance

\begin{tabular}{|l|l|l|l|}
\hline Power Distance & Taiwan & U.S.A. & Notes/ Key concepts \\
\hline $\begin{array}{l}\text { Q1. Managers should make most } \\
\text { decisions without consulting } \\
\text { subordinates. }\end{array}$ & & & $\begin{array}{l}\text { Make Decisions } \\
\text { Consulting }\end{array}$ \\
\hline $\begin{array}{l}\text { Q2. It is frequently necessary for } \\
\text { a manager to use authority and } \\
\text { power when dealing with } \\
\text { subordinates }\end{array}$ & & & Use of authority \\
\hline $\begin{array}{l}\text { Q3. Managers should seldom ask } \\
\text { for the opinions of employees. }\end{array}$ & & $\begin{array}{l}\text { Ask Opinions/ Not ask of } \\
\text { employees }\end{array}$ \\
\hline $\begin{array}{l}\text { Q4. Employees should not } \\
\text { disagree with management } \\
\text { decisions. }\end{array}$ & & $\begin{array}{l}\text { Agree/ Not disagree with } \\
\text { management }\end{array}$ \\
\hline $\begin{array}{l}\text { Q5. Managers should not } \\
\text { delegate important tasks to } \\
\text { employees. }\end{array}$ & & $\begin{array}{l}\text { Delegate/ Not delegate to } \\
\text { employees }\end{array}$ \\
\hline
\end{tabular}

Table 3 Wu, 2006 Uncertainty Avoidance

\begin{tabular}{|l|l|l|l|}
\hline Uncertainty Avoidance & Taiwan & U.S.A & Notes \\
\hline $\begin{array}{l}\text { Q1. It is important to have job } \\
\text { requirements and instructions } \\
\text { spelled out in detail so that } \\
\text { employees always know what } \\
\text { they are expected to do. }\end{array}$ & & & Detailed instructions \\
\hline $\begin{array}{l}\text { Q2. Managers expect workers to } \\
\text { closely follow instructions and } \\
\text { procedures. }\end{array}$ & & & Follow instructions and \\
\hline $\begin{array}{l}\text { Q3. Rules and regulations are } \\
\text { important because they inform } \\
\text { workers what the organization } \\
\text { expects of them. }\end{array}$ & & proces \\
\hline $\begin{array}{l}\text { Q4. Standard operating } \\
\text { procedures are helpful to } \\
\text { employees on the job. }\end{array}$ & & Importance of rules and \\
\hline $\begin{array}{l}\text { Q5. Instructions for operations } \\
\text { are important for employees on } \\
\text { the job. }\end{array}$ & & & Importance of SOP \\
\hline
\end{tabular}


Table 4 . Wu Masculinity/Femininity

\begin{tabular}{|l|l|l|l|}
\hline Masculinity/Femininity & Taiwan & U.S.A & Notes/ Keywords \\
\hline $\begin{array}{l}\text { Q1. Meetings are usually run } \\
\text { more effectively when they are } \\
\text { chaired by a man. }\end{array}$ & & $\begin{array}{l}\text { Effectiveness of men in a } \\
\text { leadership role }\end{array}$ \\
\hline $\begin{array}{l}\text { Q2. It is more important for men } \\
\text { to have a professional career } \\
\text { than it is for a woman to have a } \\
\text { professional career. }\end{array}$ & & Career importance and gender \\
\hline $\begin{array}{l}\text { Q3. Men usually solve problems } \\
\text { with logical analysis; women } \\
\text { usually solve problems with } \\
\text { intuition. }\end{array}$ & & Analytical skills and gender \\
\hline $\begin{array}{l}\text { Q4. Solving organizational } \\
\text { problems usually requires an } \\
\text { active, forcible approach, which is } \\
\text { typical of men. }\end{array}$ & & Acceptance of force and gender \\
\hline $\begin{array}{l}\text { Q5. It is preferable to have a man } \\
\text { in a high level position rather than } \\
\text { a woman. }\end{array}$ & & & \\
\hline
\end{tabular}

In 1995, Stull administered a survey developed using Hofstede’s Cultural

Dimensions to a group of students studying at San Jose State University. The students

were all enrolled in business courses. In the case of this research, demographic data was

collected on exposure to other cultures and languages. Tables five through eight show

how Stull employed questions to establish the dimensions. The researcher also employed notes to find the underlying concept behind the question. 
Table 5 Stull: Power Distance

\begin{tabular}{|c|c|c|c|}
\hline Power Distance & HPD & LPD & Notes \\
\hline $\begin{array}{l}\text { 3. The eldest male should be head of the } \\
\text { household. }\end{array}$ & * & & $\begin{array}{l}\text { Power in the } \\
\text { household }\end{array}$ \\
\hline $\begin{array}{l}\text { 15. Employees should not talk to their } \\
\text { bosses about personal matters. }\end{array}$ & * & & $\begin{array}{l}\text { Relationship } \\
\text { between } \\
\text { subordinates } \\
\text { and superiors. }\end{array}$ \\
\hline 23. Power and wealth are evil. & * & & $\begin{array}{l}\text { Cultural view on } \\
\text { Power and } \\
\text { Wealth }\end{array}$ \\
\hline $\begin{array}{l}\text { 27. It is important for managers to make all } \\
\text { decisions. }\end{array}$ & * & & $\begin{array}{l}\text { Decision making } \\
\text { preferences }\end{array}$ \\
\hline $\begin{array}{l}\text { 31. It is important that bosses closely } \\
\text { supervise their employees. }\end{array}$ & * & & Supervision \\
\hline $\begin{array}{l}\text { 7. Employees should participate in } \\
\text { company decision-making. }\end{array}$ & & * & $\begin{array}{l}\text { Decision making } \\
\text { preferences }\end{array}$ \\
\hline $\begin{array}{l}\text { 11. It is all right for employees to disagree } \\
\text { openly with their bosses. }\end{array}$ & & * & Agree/ Disagree \\
\hline $\begin{array}{l}\text { 19. It is all right for employees to call their } \\
\text { bosses by their first name. }\end{array}$ & & * & $\begin{array}{l}\text { Form of address } \\
\text { between } \\
\text { subordinates } \\
\text { and superiors }\end{array}$ \\
\hline $\begin{array}{l}\text { 35. It is important for me to be able to work } \\
\text { independently. }\end{array}$ & & * & Independence \\
\hline $\begin{array}{l}\text { 39. I like to trust and to cooperate with } \\
\text { other people. }\end{array}$ & & * & Cooperation \\
\hline
\end{tabular}

The following table shows the statements that Stull used on his survey. The asterisk indicates high or low. The notes section is the researchers evaluation on the how this links to the classroom. 
Table 6. Stull Uncertainty Avoidance

\begin{tabular}{|l|l|l|l|}
\hline Uncertainty Avoidance & LRT & HRT & Notes \\
\hline $\begin{array}{l}\text { 2. It is important to me to plan for the future } \\
\text { very carefully. }\end{array}$ & $*$ & & $\begin{array}{l}\text { The importance } \\
\text { of planning for a } \\
\text { situation. }\end{array}$ \\
\hline $\begin{array}{l}\text { 10. Company rules are always to be } \\
\text { followed. }\end{array}$ & $*$ & $\begin{array}{l}\text { The importance } \\
\text { of rules and } \\
\text { structure. }\end{array}$ \\
\hline $\begin{array}{l}\text { 18. A manager must be an expert in the } \\
\text { field in which he or she manages. }\end{array}$ & & $*$ & $\begin{array}{l}\text { Expertise in } \\
\text { field. }\end{array}$ \\
\hline $\begin{array}{l}\text { 30. Managers and bosses should be } \\
\text { selected on the basis of seniority. }\end{array}$ & & $\begin{array}{l}\text { Importance of } \\
\text { seniority }\end{array}$ \\
\hline $\begin{array}{l}\text { 38. Employees should remain with one } \\
\text { employer for life. }\end{array}$ & $*$ & $\begin{array}{l}\text { Importance of } \\
\text { loyalty. }\end{array}$ \\
\hline $\begin{array}{l}\text { 6. I enjoy taking risks. } \\
\text { 14. Organizational conflict is healthy. }\end{array}$ & & ${ }^{*}$ & $\begin{array}{l}\text { Value of taking } \\
\text { risks }\end{array}$ \\
\hline $\begin{array}{l}\text { 22. I can achieve anything I set out to } \\
\text { achieve. }\end{array}$ & & $*$ & $\begin{array}{l}\text { Acceptance of } \\
\text { some conflict }\end{array}$ \\
\hline 26. Change in my life is important to me. & & $*$ & \\
\hline $\begin{array}{l}\text { 34. It is important to be flexible during } \\
\text { negotiations. }\end{array}$ & & & \\
\hline
\end{tabular}

The following questions were used by Stull to rank Masculinity/Femininity in his study.

Table 7. Stull Masculinity/ Femininity

\begin{tabular}{|l|l|l|l|}
\hline Masculinity/ Femininity & Masculine & Feminine & Notes \\
\hline $\begin{array}{l}\text { 3. It is important for me to receive } \\
\text { recognition for my work. }\end{array}$ & $*$ & & $\begin{array}{l}\text { Personal } \\
\text { Recognition }\end{array}$ \\
\hline $\begin{array}{l}\text { 16. It is more important to me to be paid } \\
\text { well than to have a close relationship with } \\
\text { my boss. }\end{array}$ & $*$ & & $\begin{array}{l}\text { Salary vs. } \\
\text { personal } \\
\text { relationship }\end{array}$ \\
\hline $\begin{array}{l}\text { 20. It is important for me to keep my work } \\
\text { life separate from my private life. }\end{array}$ & $*$ & & $\begin{array}{l}\text { Work/ Private } \\
\text { life }\end{array}$ \\
\hline $\begin{array}{l}\text { 24. The most important things to my } \\
\text { career are a good salary and a job that I } \\
\text { do well and like. }\end{array}$ & $*$ & & Salary vs. \\
\hline $\begin{array}{l}\text { 36. People must learn to make their own } \\
\text { way in the world. }\end{array}$ & $*$ & $*$ & $\begin{array}{l}\text { Personal } \\
\text { pursuit }\end{array}$ \\
\hline $\begin{array}{l}\text { 8. My job is only one of many parts of my } \\
\text { life. }\end{array}$ & & $*$ & $\begin{array}{l}\text { career vs. other } \\
\text { aspects of life }\end{array}$ \\
\hline $\begin{array}{l}\text { 12. I would rather work for a small } \\
\text { company than a large one. }\end{array}$ & & $*$ & $\begin{array}{l}\text { small vs. large } \\
\text { organization }\end{array}$ \\
\hline $\begin{array}{l}\text { 28. It is important to shake hands before } \\
\text { all business interactions. }\end{array}$ & & $*$ & Gesture \\
\hline $\begin{array}{l}\text { 32. It is important to finish one interaction } \\
\text { before rushing off to another. }\end{array}$ & & $*$ & $\begin{array}{l}\text { Linear } \\
\text { interactions }\end{array}$ \\
\hline $\begin{array}{l}\text { 40. People will achieve organizational } \\
\text { goals without being pushed. }\end{array}$ & & $\begin{array}{l}\text { No need to } \\
\text { push }\end{array}$ \\
\hline
\end{tabular}


The following table gives questions used by Stull to evaluate Individualism/Collectivism in his study. The notes were made by the researcher to attempt to envision the underlying thoughts behind the questions.

Table 8. Stull Individualist/ collectivist

\begin{tabular}{|c|c|c|c|}
\hline & Individualist & Collectivist & Notes \\
\hline $\begin{array}{l}\text { 5. If an individual thinks of a different way } \\
\text { to perform a task, that person should be } \\
\text { encouraged to do it that way. }\end{array}$ & * & & $\begin{array}{l}\text { Value of } \\
\text { individual } \\
\text { thoughts }\end{array}$ \\
\hline $\begin{array}{l}\text { 13. It is important that people have lots of } \\
\text { free time to pursue their own interests. }\end{array}$ & * & & $\begin{array}{l}\text { Value of } \\
\text { individual } \\
\text { interests }\end{array}$ \\
\hline $\begin{array}{l}\text { 21. When children become } 21 \text { years of } \\
\text { age, they should be encouraged to move } \\
\text { away from home. }\end{array}$ & * & & $\begin{array}{l}\text { Value of } \\
\text { independence }\end{array}$ \\
\hline $\begin{array}{l}\text { 25. It is important that I receive individual } \\
\text { recognition at work. }\end{array}$ & * & & $\begin{array}{l}\text { Value of } \\
\text { individual } \\
\text { recognition }\end{array}$ \\
\hline $\begin{array}{l}\text { 33. When I work on group projects, it is } \\
\text { important for me to be the leader. }\end{array}$ & * & & \\
\hline $\begin{array}{l}\text { 1. It is important that people conform to } \\
\text { company norms in order to reach company } \\
\text { goals. }\end{array}$ & & * & \\
\hline $\begin{array}{l}\text { 9. I would always cooperate to keep } \\
\text { company harmony. }\end{array}$ & & * & \\
\hline $\begin{array}{l}\text { 17. Parents have the right to choose the } \\
\text { spouse for their children. }\end{array}$ & & * & \\
\hline $\begin{array}{l}\text { 29. If I were given a large sum of money, I } \\
\text { would share it equally with members of my } \\
\text { family. }\end{array}$ & & * & \\
\hline $\begin{array}{l}\text { 37. When working on a project, I would } \\
\text { rather work as a group member than as an } \\
\text { individual }\end{array}$ & & * & \\
\hline
\end{tabular}

\section{Culture and Education: A Communication Perspective}

To understand how culture affects human development there is a need to define culture, and how cultures may differ in an educational setting. When most people think about culture they normally think about the food, language, and arts of a specific group of people-or, as the literature suggests "High Culture" (Boundless, n.d.) High-culture is normally taught explicitly to members of the group as part of their cultural heritage. Another way of looking at this would be things that the members of that culture would put in a time capsule for others to find. In contrast "Low Culture", is the everyday 
activities of a people. Low culture encompasses all the underlying values of a culture such as defining correct conduct or appropriate gender role. Typically the education system of a country is considered a part of its low culture for it establishes what is taught, how members of the society are taught as well as which members are educated.

How each culture educates their population will also differ from culture to culture. There are three main things that can be understood by knowing how a culture teaches:

- The basic core values of the culture,

- The expected interpersonal relationships in the classroom,

- Social relationships.

These are a crucial part of a child's integration into society.

\section{Culture and Learning}

A relationship can be found between culture and the style of learning preferred by the members of that society. While this may vary among members of a society it can be established as a society standard. (Samovar, Porter \& McDaniel, 2008 p., 267-268) The list below was interesting because of its relationship to masculine/feminine styles. This could relate to learning or teaching style. It would be beneficial to see if this applied to individual designers, or to cultural qualities.

\footnotetext{
$\checkmark$ Trial and Error

$\checkmark$ Motivation

$\checkmark$ Tolerance for Ambiguity

$\checkmark$ Learning and Receiving
} 


\section{Culture and the Instructional Designer: What are we, as designers, taught about culture?}

While instructional designers need to be aware of these different learning styles and how to deal with them when they come together in a classroom they also need to be able to understand their own perception on design. This is not typically taught in instructional design textbooks. Educational researchers need to be aware of their assumptions and how this can create research bias. Likewise instructional designers could benefit from being aware of their own cultural-boundedness. Just as research bias can lead to inaccurate reporting of information and can cause a witness to ignore, distort, or overemphasize incidents (McMillan 1997, p. 478) designer bias may lead to inappropriate or ineffective instruction.

To establish where the explicit design decisions come from it is important to look at the textbooks used to teach instructional designers. These textbooks used do not normally include discussion on the implicit design decisions designers make. Talking with American designers and instructors it is understood that Japanese students are quiet in the classroom and do not offer information in class willingly, but the reason behind this is not included. What is included in the curriculum design text is the designer must be aware the language barriers that may be faced by non-native students. By understanding the reasoning behind this behavior would the designer make different decisions?

Technology is also a factor in the new classroom dynamics. Around the world students and educators are making more use of technology in education in the form of online or blended learning environments. Universities are asking instructors to 
incorporate technology into their courses that may then be available to students from round the world. This has created an environment where culturally diverse student populations come together.

\section{Chapter Summary}

Most of the research done on culture in the classroom dealt with the effect of culture on the student. Of major importance is the ability to integrate students from various cultures into the classroom. This study shifts the research focus onto the instructor and instructional designer.

Using the data from the pilot study, as well as current trends in education, it was proposed that an expanded project be undertaken. This research is important because of the changing educational system at all levels. At the public school level immigration is creating a diverse student base. At the tertiary level there is an increase in international students. Technology has also created an impact on instructional design process by bringing students from around the world together. Creating an environment where educational culture is explicitly understood could establish more effective interventions. 


\section{CHA P T E R 3: ME THO D O L O G Y}

\section{Research Design Overview}

The two research questions involve instructional designers developing an explicit understanding of their cultural-boundedness. The first question is "Does the development of this self-awareness cause the participant to add additional design elements into their instructional design projects? The second question is "Do they make different design decisions than they had before? The study consisted of three phases and was Quasiexperimental in design. The first section was a personal survey, and instructional design sample, which served as a baseline for evaluating the effects of the intervention. The intervention part was second, with the post intervention sample last.

The methodology for this project is based on the pilot study done in 2010 . Consisting of an eleven-question survey, and a follow up interview with the participants. This was effective for discovering if Hofstede's Model of Cultural Dimensions was useful in predicting participant response depending on background culture. This project uses a similar survey and the collection of a design sample to formulate a baseline for the participants design tactics.

\section{Pilot Study: The First Steps}

Before this project could be started it was important to discover several facts. First was Hofstede's model an accurate tool at predicting decisions different cultures would make when designing instruction as opposed to a business setting? To determine this, a pilot study was done using a short survey created by the researcher. The results from this study were analyzed to determine if further study in this area was warranted. 
"The literature review and the researcher's personal experience abroad, provided some initial background in cultural expectations in the classroom. This study served as a pilot study to find out if it is possible to isolate these implicit culturalbounded decisions. It led to the question formulated for the current research: By making these implicit culturally bound design decisions explicit how do we change the way that instructional designers design for a multi-cultural classroom." (Hando, 2010)

\section{Instrument (Pilot study)}

Development of the instrument was crucial in the development further research projects. The initial survey developed for the pilot study was used to gather initial demographic information on the participants. In the pilot study it was the single instrument used. This was combined with other data collection to form the dissertation project. The purpose of the pilot study was to determine if Hofstede's Model of Cultural Dimensions could be used to rate decisions instructional designers make. In order to do this a series of questions were created. The first set of questions established the cultural background of the participant. In order to determine if background culture has an effect on instructional design these questions helped to establish the baseline for the participants. The second section allows the participant to give information on their culturally based design decisions. Additionally the questions were constructed so that they would provide culturally relevant educational background information. Care was also taken in the design of the survey in order that they could be used to rank the culture according to Hofstede's Model. What was found in that study was that Hofstede's Model was a good tool to use when discussing instructional design practices. 
The researcher conducted a short online survey, which was followed by an asynchronous interview with some of the subjects. (See Appendix 1) The answers were then compared to traits considered part of the educational culture of the participant using Hofstede's Model of Cultural Dimensions. This allowed us to determine if the participant responds in a way that exhibits their underlying cultural beliefs. This will allow affirmation of where these differences are, and if there is need for intervention.

\section{Instrument:}

Question 1: "What is your nationality?" supplied the baseline question for the survey. In order to discover if Hofstede's Model of Cultural Dimensions is an accurate predictor of preferred teaching styles it was necessary to determine if there was a correlation between the expected outcomes and the actual outcomes of the survey and interview. Given a high number on the scale Hofstede's model in Independence/Collectivism, then it is expected that this culture would prefer individual tasks, while cultures that scored low could be expected to prefer group oriented tasks.

Question 2: "What was your major?" The intent behind this question is to gain some understanding into how background education affects the instructional design process. Does an educational background in instructional design change the way that people design? We expected teachers without an ID background, would draw upon their cultural experiences in the classroom as they design instruction.

Question 3: "Have you ever studied in another country?" Realizing that previous exposure to a classroom environment outside their own country can have an influence on their design it necessary to include a question in the survey to account for this variable.

Question 4: "What were your favorite activities in the classroom as a child?" The expectation is that designers will include those activities into their own classroom designs. These answers were examined to compare where these activities might fall within Hofstede's model. By having the participant talk about their past educational experiences they would not relying on what they think may be expected of them as professional educators. It might also give some insight into the educational culture the participant grew up in. Current educational standards may support 'child centered' classrooms, so participants may feel that they should answer respond use activities that encourage this, but if their culturally based 
design experience does not include this they may find themselves conflicted in their design.

Question 5: "How much interaction did you have with your instructor?" The choices offered were: "lecture oriented", "encouraged interaction", and "It depended on the class". The answers to this question were then compared to Hofstede's model of Cultural Dimensions to see how the Power Distance of a culture compared to the teaching style. Do cultures, which have a lower Power Distance score offer more opportunities to speak out in class?

Question 6: "How upset would you be if you did not know the answer to a question in class?" This was then compared to Hofstede's model and the rating of Tolerance for Ambiguity. It could be assumed that cultures who have a low tolerance for ambiguity would be respond that it would make them more upset. Question 7: "What kind of classes do you design?" The intent of this question is to gather information on the subject the designer is use to designing for.

Question 8: “Are you the teacher and the designer?" In many cases the instructor is the designer of the class. This, combined with other information from the survey will allow a better understanding of how teachers not trained in ID handle the design process. If the designer is not the instructor then it will be important to understand how they work with the SME's.

Question 9: "How many years of experience do you have in Instructional Design?" The participants were asked to choose the amount of time they have had doing instructional design. The style of design they prefer may change depending on experience.

Question 10: "What age group do you design for?" This question will have an effect on the designer's classroom expectations. Those designing for adult learners will probably design with a closer power distance expectation. The learner will be expected to take charge of their learning.

The survey was filled out online via a secure server hosted by a Mid-Atlantic University website using an unpublished survey application called Skipper(Ahern, 2010). The participants were given a User_ID and a Password so that they could enter the site and fill out the survey. The data was collected anonymously, stored on the server and then downloaded onto a spreadsheet. 


\section{Results of the Pilot study}

The results of the study indicated that Hofstede's Model was an accurate predictor of participant response. Not all the survey questions were traced back to Hofstede, but were intended to gather demographic information as well as Educational Belief perspectives. The results were placed into graphs to search for patterns in response. For example, Question number six could be directly related to uncertainty avoidance. As expected the American participants were, overall, more tolerant of uncertainty. What was found was that, while there was variation within the culture the tendency did suggest cultural norms.

The next stage of this study was the intervention. Two sets of surveys, which used Hofstede's Model, were used as models for questions about the participants' educational beliefs. The participants were given the results of this survey and then feedback on where they stood on Hofstede's Model. This would create an individual assessment. Given their response to the questions they were given feedback on what their style was and some examples of how to look at the other side of the dimension. In developing the intervention care was taken to ensure that each perspective was treated without bias.

\section{Participants}

The participants for the pilot study were drawn from a variety of cultures, backgrounds, and in people who have experienced classrooms with a diverse student population. This was to test the accuracy of Hofstede's Model over a broad spectrum. For this study there was a cultural concentration on American and Japanese participants. Participants were drawn from groups of students participating in an instructional design program at two universities in America, and another in Japan. Another criteria was 
teaching experience in multi-cultural classrooms. It was important that the participants had some experience teaching. Formal training in instructional design, outside of what was included in any education classes, was not important. Gender was not a consideration in this study. A sample of 13 instructional designers was gathered from various cultures. The responses given were evaluated and compared to find any cultural similarities.

The purpose of the pilot study was to determine if Hofstede's Model of Cultural Dimensions could be used to rate, or even predict, decisions instructional designers would make. In order to do this a series of questions were created. The first set of questions established the cultural background of the participant. In order to determine if background culture has an effect on instructional design these questions helped to establish the baseline for the participants. The second section allows the participant to give information on their culturally based design decisions. Additionally the questions were constructed so that they would provide culturally relevant educational background information. Care was also taken in the design of the survey, so that the answers could be used to rank the culture according to Hofstede's Model. This was done by using two other established surveys, and changing it so that instead of boss and employee it was teacher and student.

The researcher conducted a short online survey first, which was followed by an asynchronous interview with some of the subjects. The answers were then compared to traits considered part of the educational culture of the participant. This allowed us to determine if the participant responds in a way that exhibits their underlying cultural beliefs. This will allow affirmation of where these differences are, and if there is need for intervention. 


\section{Part One: Establishing the Baseline}

Initial Survey: The survey used was established in the pilot study. An added element in this survey was a question regarding culture. This was introduced to allow consideration of Hofstede's scale of Masculinity/Femininity. This was the only change made to the introductory survey.

The survey was filled out online via a secure server hosted by a Mid-Atlantic University website using an unpublished survey application. The participants were given a User_ID and a Password so that they could enter the site and fill out the survey. The data was collected anonymously, stored on the server and then downloaded onto a spreadsheet. (Expectation: Instructional designers from the same culture will make similar design choices reflecting cultural expectations in the classroom.)

1. Teacher control

2. Student participation

3. Preferred tasks

4. Evaluation methods

Data could be analyzed to reflect typical design choices that cultures make, as well as how to make improvements on their design.

\section{Collecting the initial design sample:}

In addition to the initial survey it was decided that a design sample would be collected to provide information on the participant's design ideas before the intervention. The participants were given a scenario and asked to design a fifty to sixty minute instructional sequence. They were not asked to provide the learning activities, but to describe the type of learning objectives they had, and the learning activity sequence. The choice of topic, favorite holiday, was given to the participants. The learners were 
described as young adults between eighteen and twenty-four. Using a planned scenario would provide some consistency in the projects, and allow for effective analysis.

\section{Second Part: The Intervention}

The intervention consisted of 20 questions developed from research on Hofstede's Model of Cultural Dimensions. Four of Hofstede's dimensions were chosen and five questions developed to elicit background response according to a Likert scale. The participants were told that this was a survey of their educational beliefs, and that there was no right or wrong answer.

\section{Feedback}

Using Moodle's selective release function the participants were given feedback on their response to each of the four dimensions. The feedback included where they scored on the scale, using a high-low response, a short description of Hofstede's Model, what countries were similar to their background, and finally a sample of the other side of the coin. The feedback was created with neither side being shown as right or wrong.

\section{Third part: Second data collection}

The participants were then asked to reflect on what they had learned about themselves, and make any revisions on their design sample that they thought would improve it given this new information.

\section{Hofstede's Model: A tool for cultural comparison.}

As stated in the introduction of this paper, one of the objectives of this project was to find a tool to use to evaluate the decisions that instructional designers make. Even though Hofstede's Model of Cultural Dimensions was developed for international 
business communication translating this tool for use in the classroom did not seem to be that difficult. The same cultural dimensions, that Hofstede uses to compare cultures in business, seem to be an underlying part of an individual's personal background. Table nine below shows the implications and expectations for the survey questions asked can be related to Hofstede's model.

Table 9: Survey Design Chart Pilot Study

\begin{tabular}{|c|c|c|}
\hline Number 2: Major & $\begin{array}{l}\text { Does training overcome culture? } \\
\text { This serves to give background } \\
\text { information on the participant. }\end{array}$ & $\begin{array}{l}\text { People with no training in ID will } \\
\text { rely on their background } \\
\text { culture. }\end{array}$ \\
\hline $\begin{array}{l}\text { Question 3: Study } \\
\text { Abroad/Living abroad }\end{array}$ & $\begin{array}{l}\text { Does experience with other cultures } \\
\text { influence design? Background } \\
\text { information on the Participant. }\end{array}$ & $\begin{array}{l}\text { People who have lived abroad } \\
\text { will be more culturally flexible. }\end{array}$ \\
\hline $\begin{array}{l}\text { Question 4: Favorite } \\
\text { Activities }\end{array}$ & $\begin{array}{l}\text { Can we establish a link between the } \\
\text { activities exposed to and } \\
\text { participants design style? } \\
\text { This could be looked at as a Power } \\
\text { Distance ranking or an Individualist } \\
\text { ranking. }\end{array}$ & $\begin{array}{l}\text { Expect that they will design } \\
\text { close to the way they were } \\
\text { taught }\end{array}$ \\
\hline $\begin{array}{l}\text { Question 5: Amount of } \\
\text { contact with instructor }\end{array}$ & $\begin{array}{l}\text { Can we establish a link between } \\
\text { teaching style and Hofstede's } \\
\text { Dimension of Power Distance? } \\
\text { This was a Power Distance ranking } \\
\text { question. }\end{array}$ & $\begin{array}{l}\text { Expect that the amount of } \\
\text { contact will relate to the power } \\
\text { distance ranking of a culture. }\end{array}$ \\
\hline $\begin{array}{l}\text { Question 6: Fear of not } \\
\text { knowing the answer to a } \\
\text { question. }\end{array}$ & $\begin{array}{l}\text { Can we establish a link between } \\
\text { fear of not knowing the answer and } \\
\text { the Uncertainty Avoidance ranking } \\
\text { of a culture? } \\
\text { This was an uncertainty Avoidance } \\
\text { question. }\end{array}$ & $\begin{array}{l}\text { Those cultures with higher } \\
\text { Uncertainty Avoidance rankings } \\
\text { will report a greater fear of not } \\
\text { knowing. }\end{array}$ \\
\hline Question 7: Kind of classes & $\begin{array}{l}\text { Does the type of class being } \\
\text { designed determine the way the } \\
\text { class is taught? }\end{array}$ & $\begin{array}{l}\text { Different of classes may have } \\
\text { different design expectations. }\end{array}$ \\
\hline $\begin{array}{l}\text { Question 8: Designer and } \\
\text { Instructor? }\end{array}$ & $\begin{array}{l}\text { Does design experience affect } \\
\text { culture? How much are the } \\
\text { participants relying on their } \\
\text { background culture? }\end{array}$ & $\begin{array}{l}\text { If the instructor is also the } \\
\text { designer their training in } \\
\text { Instructional design may be } \\
\text { limited, so they will design } \\
\text { using their background culture. }\end{array}$ \\
\hline $\begin{array}{l}\text { Question 9: Years of } \\
\text { experience in Instructional } \\
\text { Design }\end{array}$ & $\begin{array}{l}\text { How does experience in ID affect } \\
\text { the design? }\end{array}$ & \\
\hline
\end{tabular}




\begin{tabular}{|l|l|l|}
\hline $\begin{array}{l}\text { Question 10: Age group } \\
\text { designed for. }\end{array}$ & $\begin{array}{l}\text { Are there different expectations } \\
\text { when designing for different age } \\
\text { groups? }\end{array}$ & $\begin{array}{l}\text { We may shift the Power } \\
\text { Distance expectations as the } \\
\text { age of the student goes up. We } \\
\text { may change activity choices } \\
\text { depending on the age of the } \\
\text { student. }\end{array}$ \\
\hline
\end{tabular}

\section{Procedure}

Gathering the participants for this study involved finding a group of multinational instructional designers. The Instructional Design and Technology program at WVU has students from around the world, so this was not a difficult task. Personal contacts in Japan were used to expand participant base.

An email was sent to potential participants giving a short explanation of the project and its goal. Included in this email was what would be required if they decided to participate. This purposeful sampling of potential participants was used to include as many cultures as possible.

After finding willing participants a formal letter of intent was sent. This allowed them to change their mind if they needed to without a problem. The formal letter of intent included contact information and a timeline for the project. A follow-up letter was sent with information on how to access the survey and directions needed to complete the survey. This did not require the participants to input any data that could easily be used to distinguish them.

The survey results were collected on Skipper and then analyzed. The surveys were completed over a two-week period. Skype interviews with some of the subjects were done with some of the participants. These were transcribed using no names, but a participant number and a country of origin. 
In order to try to get a clear picture of how cultural background affects the design experience it is helpful to look at the activities that the participants remember fondly. The next question looks at participants past experience as well. The amount of interaction that they had with their teachers could relate to the Power Distance scale in Hoffstede's model.

An overview of the five dimensions is given below in table 10. The name and a definition of the dimension is provided. Table eleven shows the ranking established by Hofstede in his initial study.

Table 10 Overview of Hofstede's Model of Cultural Dimensions

\begin{tabular}{|l|l|l|}
\hline Dimension One & Power Distance & $\begin{array}{l}\text { The amount of acceptance } \\
\text { that a culture has towards } \\
\text { unequal distribution of } \\
\text { power. }\end{array}$ \\
\hline Dimension Two & Individualism/ Collectivism & $\begin{array}{l}\text { The strength of ties that a } \\
\text { culture holds. }\end{array}$ \\
\hline Dimension Three & Masculinity/Femininity & $\begin{array}{l}\text { This refers to the gender } \\
\text { roles within a society }\end{array}$ \\
\hline Dimension Four & Uncertainty Avoidance & $\begin{array}{l}\text { The general level of anxiety } \\
\text { towards the unknown that a } \\
\text { culture has. }\end{array}$ \\
\hline Dimension Five & Long term/Short term orientation & $\begin{array}{l}\text { The influence of tradition on } \\
\text { a culture. }\end{array}$ \\
\hline
\end{tabular}

Table 11: Established Ranking of participant culture by Hofstede's Model

\begin{tabular}{|l|l|l|l|l|}
\hline Culture & Power Distance & Individualism & Masculinity & $\begin{array}{l}\text { Uncertainty } \\
\text { Avoidance }\end{array}$ \\
\hline American & 40 & 91 & 62 & 46 \\
\hline Japanese & 54 & 46 & 96 & 92 \\
\hline African & 64 & 27 & 41 & 52 \\
\hline Malaysian & 104 & 26 & 50 & 36 \\
\hline
\end{tabular}




\section{Initial Design Data Collection}

Once the participants had filled out the revised survey giving some background information they were asked to make some choices about design preferences as a baseline to establish if the intervention had any effect on the design outcome. The participants were given a short background on the students they would be designing for. Then they were given choices on how they would structure the lesson. How would they introduce the topic? What kind of activities would they choose? In order to make this item easier to evaluate a template was used to gain consistency.

They were asked to choose how they would introduce the topic. The choices included methods that would directly introduce the topic. A preference for this method would indicate a preference for avoiding uncertainty. Having the instructor directly introduce the topic could also indicate a higher power distance score. Indirect methods of introducing the topic, such as the instructor presenting a problem, would indicate less uncertainty avoidance.

The body of the lesson was divided into several categories. Power distance choices included direct instruction methods, such as teacher lecture, were included. Indirect instruction methods such as student exploration, was considered another example of lower Power Distance. Individualism/Collectivism choices were given. The developer could also choose group or individual activities to add to their design. 


\section{Intervention}

The intervention consisted of having the participant answer five questions about their educational beliefs for each of the four dimensions being considered. To develop this intervention two other surveys used by researches to evaluate response to certain questions were used. In one case this required the researcher to switch the authority figure referred to in the question to the instructor rather than the boss. Participants were then given the results of their survey and suggestions were made. To create the intervention questions several surveys that had been used to generate data on Hofstede's model were reviewed and the questions translated to an educational setting. For example, if a business survey asked about the way managers made decisions then this was translated to teachers making decisions in the classroom. (Appendix 6) Moodle and the selective release function was used to provide feedback on the response to the questions.

\section{The Coin Model}

While designing the intervention the researcher considered the terms being used by Hofstede to describe the dimensions. Hofstede chooses to use High and Low to describe cultural rankings on the Power Distance scale. Other terms, such as individualism and collectivism, may be looked at with varying degrees of tolerance from different cultures. American's tend to take pride in the fact that they are independent. They may look at the term collectivist with more of a negative mindset. To reduce the bias that may come from these terms the idea of a "Coin" was considered. It does not matter which side of the coin you are on. It was considered more important to be able to 
see the other side. The implication of this is that, when the feedback was being given, the response should be positive while showing how to include the other side of the coin.

\section{Delivering the Intervention: Moodle}

Another consideration that had to be made was the delivery tool to be used for delivering the intervention. Some of the considerations for delivery systems were Moodle, ECampus, or Sakai. These systems all have tools that would allow for email, virtual classrooms, and the creation of learning modules including evaluations. For the intervention we started with a PowerPoint that included five questions. Once the participant had answered the five questions for that particular Educational Belief Quiz they were then sent by selective release to one of two PowerPoint presentations.

\section{Redesign and Reflect}

The final part of data collection asked the participants to redesign the class that they had originally proposed. This time the participants were given a chance to reflect on the decision they were making. This was analyzed to discover if the intervention prompted changes, and what type of changes were made.

\section{Data Analysis}

The data from the initial survey and the initial design collection will be analyzed compared to Hofstede's Model of Cultural Dimensions. One of the things we would like to learn is if the cultural background someone grows up in affects their design practices. The initial survey asks what country the participant is from. Having multiple participants from the same culture we can analyze the response of those participants and evaluate how they compare to Hofstede's expectations. The initial design collection will be analyzed 
through Hofstede's model to see how the chosen activities, tools, and other factors fall within those dimensions. Instructional designers from high power distance countries may not include students in the decision making process. There may not be a choice of projects, or rules may be teacher driven. The researchers had the participants design for an adult audience to account for any age related power distance expectations.

The intervention questions will be analyzed and students will be given feedback. The model accounts for one side of the coin or the other. Taking the five questions we informed the participants which side of the coin they fell on. "You are somewhat high power distance."

\section{Limitations of Methods:}

One of the limitations of this method was that the sample size was small. In future research it would be helpful to add additional data from other classes of instructional designers. Because Japan has limited programs in instructional design it limited the number of participants for this survey.

Another limitation of the methodology would be the previous assumptions made by Hofstede, and others who follow his work. In this case we tried to overcome the survey method by including reflections by the participants.

This study does compare the cultural response of instructional designers, but it assumes that change can be made. (Study abroad has long been seen as beneficial because it gives students a different view. This may be one way of enabling designers to gain a different perspective.) We found in the pilot study that there is variation within the culture, but that in general there are some consistencies. We use additional feedback to evaluate the design. 
Assumptions of Hofstede's model (McSweeney, N.D.)

\section{Assumptions:}

1. Every Micro-Location is typical of the National Culture

2. Respondents were already permanently "mentally programmed" with three non-interacting cultures.

3. The main dimensions of a national culture can be identified by questionnaire response difference analysis.

4. That "identified" in the workplace is unaffected by location. 


\section{CHA P T ER 4: RESULTS}

\section{Overview}

The purpose of this research was to investigate the influence cultural background has on instructional design decisions, and if an intervention using Hofstede's Model of Cultural Dimensions would be effective in creating cultural self-awareness.

Research question one asks if an instructional designer becomes self-aware of their own cultural-boundedness will this influence the design decisions instructional designers make in developing the lesson... To establish if the instructional designers reacted to the questions in a way that would be comparative to Hofstede's test back in the eighties the pilot study it was conducted and it indicated that the participants fell within the range that Hofstede reported.

Question 1: Does the development of this self-awareness cause the participant to add additional design elements into their instructional design projects?

Question 2: Do they make different design decisions than they had before?

The concept of a coin model was crucial to this project. Instead of looking at these elements of culture as 'right' or 'wrong', which would create critical implications for the participant, the intent was to create a neutral environment in which to review design decisions.

Part one of the study was designed to establish the demographic and instructional design background of the participants. A survey of eleven questions was administered to gather relevant information. The introductory survey consisted of two parts. The first part 
had the participants respond to questions about their background. The second part of the survey queried them about their instructional design experience. Next, each participant submitted an instructional design sample. The participants were given a scenario, and then asked to provide a sample of how they would design the instructional event (Appendix 2).

Part two of the study is the intervention. Participants were provided with a fivequestion quiz for each of the four dimensions of Hofstede's Model. (Appendix 3) Based on their answers they were provided with targeted instruction through a PowerPoint presentation, which was to make them aware of their cultural background.

The Final section of the study allowed the participants, given their new knowledge, to revise their initial design sample. This would then be compared to their initial design sample to establish where any changes took place. Additionally an exit interview conducted through an online chat.

\section{Part 1: Introductory Survey and Initial Design Sample}

The initial survey information was divided into three sections designed to elicit specific information from the participants. The first section included the participants' educational background and demographic information, which would be used to create a baseline before the intervention. The second section included two questions on individual learning preferences. The last section included information on their design and teaching experience.

The educational information was used to evaluate how their cultural and educational background would reflect Hofstede's Model. The second section also looked 
at their design experience, in particular the subject matter being taught and age range they have experience with.

There were two major criteria for inclusion into this study. The first was instructional design experience. This could take the form of practical experience designing and delivering instructional experiences. The second criterion was past or present teaching experience. The participants fell into two groups, those that were in the instructional design field, and those who are currently teaching. The participants were found in a similar method to the Pilot Study. Some were members of the IDT Department at WVU. Others were found through connections on LinkedIn. To eliminate bias none of the participants were involved in the Pilot Study.

Twelve participants completed all phases of the study (Table 12). From the Northern American region there were six Americans, and one Canadian. From the South American Continent we had one participant from Venezuela. From Western Africa we had two participants, one from Ghana and one from Nigeria. From Asia we had two participants, one from China and one from Japan. All of these countries had been giving a ranking on Hofstede's original model.

Table 12: Demographic Information
\begin{tabular}{|l|l|l|l|l|}
\hline $\begin{array}{l}\text { Participant } \\
\text { Number }\end{array}$ & Q1 Nationality & Q2 Gender & Q3 Major & $\begin{array}{l}\text { Q4 Study } \\
\text { Abroad }\end{array}$ \\
\hline Part 1 & American & Male & IDT & Yes \\
\hline Part 2 & American & Female & IDT & No \\
\hline Part 4 & Ghanan & Male & Psychology & Yes \\
\hline Part 5 & American & Female & ED & No \\
\hline Part 6 & Venezuelan & Female & For. Lang. & Yes \\
\hline Part 7 & Nigerian & Male & Tech Ed & Yes \\
\hline Part 8 & Chinese & Female & IDT & Yes \\
\hline Part 9 & American & Female & IDT & Yes \\
\hline Part 11 & Japanese & Female & Literature & Yes \\
\hline Part 13 & American & Female & TESOL & No \\
\hline Part 14 & American & Female & Educational & Yes \\
\hline Part 15 & Canadian & Female & Technology & Psychology \\
\hline
\end{tabular}


There were nine females and three males who participated in this study. A majority of the participants, eight out of twelve, had degrees involving education. Nine of the participants had either lived or studied abroad.

\section{Personal Preference Questions}

Another area of interest revolved around personal preferences and experiences. A person's past educational experiences has been found to have an influence on their present instructional design practices. The assumption is that activities that were enjoyed as a student will be included in the classroom as a teacher or designer. What was found was a wide range of activity preferences, so they were divided into categories as illustrated in Table 13

Table 13: Survey Question 5 favorite activities
\begin{tabular}{|l|l|l|l|}
\hline Group & Individual & Active & Passive \\
\hline Discussion & Independent Projects & Presentations & Reading \\
Part 4 & Part 2 & Part 1 & \\
Part 9 & & Part 7 & \\
\hline Small group & & Round Table & Listening to Lectures \\
projects & & Part 8 & P15 \\
Part 5 & & & \\
Part 6 & & & \\
\hline
\end{tabular}

Initial Survey Question six was intended to establish the educational culture that the participant had previously experienced. The expectation was that, given previous exposure to a high power distance culture, participants would respond that class format would be lecture based instead of discussion. This was not the case.

The expectations of the results on questioning the level of interaction with the instructor and the Power Distance rating of the culture indicated a correlation between the class and the amount of interaction (Table 15). The American participants responded 
widely to this question. One possible reason for the wide disparity could be that the subject being taught could influence the amount of participation.

Table 14: Question 6: Interaction with Instructor
\begin{tabular}{|l|l|l|}
\hline $\begin{array}{l}\text { The instructor talked, I } \\
\text { took notes }\end{array}$ & It depended on the class & $\begin{array}{l}\text { The instructor encouraged } \\
\text { questions in class }\end{array}$ \\
\hline High Power Distance & & Low Power Distance \\
\hline Part 4 & $\begin{array}{l}\text { Part 7, Part13, Part 6, Part 8, } \\
\text { Part 9, Part 7, Part 11, Part 13, Part } \\
14,\end{array}$ & Part 1, Part 5, Part 2 \\
\hline & $\begin{array}{l}\text { More middle answers overall } \\
\text { American Participants seemed to be } \\
\text { either high or low on this question. }\end{array}$ & \\
\hline
\end{tabular}

\section{Participant Design Experience}

Questions eight through eleven were concerned with the design experience of the participants. (Table 15) In the initial study (Hando, 2012) a possible link was found between the subjects being taught and the instructional design tools being used. 
Table 15 Question 8 Design Experience

\begin{tabular}{|c|c|c|c|c|}
\hline Participant & $\begin{array}{l}\text { Question } 8 \\
\text { Classes Taught }\end{array}$ & $\begin{array}{l}\text { Question } 9 \\
\text { Designer/ } \\
\text { Instructor }\end{array}$ & $\begin{array}{l}\text { Question } 10 \\
\text { Years of Experience }\end{array}$ & $\begin{array}{l}\text { Question } \\
11 \\
\text { Student } \\
\text { age base }\end{array}$ \\
\hline Part 1 & $\begin{array}{l}\text { Spanish } \\
\text { Wood science }\end{array}$ & No & Over 5 & $18-24$ \\
\hline Part 2 & Computer use & Yes & $3-5$ & $24+$ \\
\hline Part 4 & $\begin{array}{l}\text { Statistics } \\
\text { Research Methods }\end{array}$ & Yes & $1-3$ & $24+$ \\
\hline Part 5 & $\begin{array}{l}\text { Soft Skills } \\
\text { Technical skills }\end{array}$ & $\mathrm{Ye}$ & Over 5 & $24+$ \\
\hline Part 6 & $\begin{array}{l}\text { Spanish } \\
\text { ESL }\end{array}$ & Yes & Over 5 & $18-24$ \\
\hline Part 8 & $\begin{array}{l}\text { Service Training } \\
\text { Articulate }\end{array}$ & No & Over 5 & $24+$ \\
\hline Part 9 & None & No & $1-3$ & $24+$ \\
\hline Part 11 & $\begin{array}{l}\text { Hardware } \\
\text { Software } \\
\text { Technology } \\
\text { Media }\end{array}$ & Yes & $1-3$ & $24+$ \\
\hline Part 12 & Marketing & Yes & Over 5 & $24+$ \\
\hline Part 13 & $\begin{array}{l}\text { Communication } \\
\text { Math }\end{array}$ & Yes & $1-3$ & $13-18$ \\
\hline Part 14 & $\begin{array}{l}\text { Highway engineering } \\
\text { Border Patrol }\end{array}$ & No & Over 5 & $24+$ \\
\hline Part 15 & $\begin{array}{l}\text { ESL writing } \\
\text { Presentation }\end{array}$ & Yes & Over 5 & $24+$ \\
\hline
\end{tabular}

The initial design sample was analyzed by looking for key-words that would help identify the learning style being used, which would then be related to Hofstede's Model of Cultural Dimensions.

The MindTools website was used to come up with the key words by looking at the characteristics and tips for each dimension. (Mind Tools, n.d.) 
Table 16: Key words

\begin{tabular}{|c|c|c|c|c|}
\hline Dimension/Keywords & $\begin{array}{l}\text { High } \\
\text { Keywords }\end{array}$ & $\begin{array}{l}\text { High } \\
\text { Activities }\end{array}$ & $\begin{array}{l}\text { Low } \\
\text { Keywords }\end{array}$ & $\begin{array}{l}\text { Low } \\
\text { Activities }\end{array}$ \\
\hline Power Distance & $\begin{array}{l}\text { Teacher } \\
\text { directed }\end{array}$ & Lecture based & $\begin{array}{l}\text { Student } \\
\text { directed }\end{array}$ & $\begin{array}{l}\text { Inquiry } \\
\text { based }\end{array}$ \\
\hline Independence & Student needs & $\begin{array}{l}\text { Individual work } \\
\text { Activities allow for } \\
\text { the individual }\end{array}$ & $\begin{array}{l}\text { Respect age } \\
\text { Become } \\
\text { expert }\end{array}$ & Group Work \\
\hline $\begin{array}{l}\text { Masculinity } \\
\text { Femininity }\end{array}$ & $\begin{array}{l}\text { Reward for } \\
\text { good work }\end{array}$ & & $\begin{array}{l}\text { Emphasis on } \\
\text { feelings }\end{array}$ & \\
\hline Uncertainty Avoidance & $\begin{array}{l}\text { Explicit } \\
\text { directions } \\
\text { Expect } \\
\text { structure }\end{array}$ & & & \\
\hline
\end{tabular}

The initial survey (Appendix 1) collected information in two areas: the student's cultural/educational background, and their instructional design experience.

Table 17: Survey Expectations

\begin{tabular}{|l|l|}
\hline Question & Expectations \\
\hline 1: Nationality & Compare to cultural norm established by Hofstede \\
\hline 2: Gender & Gender might influence design choices \\
\hline 3: College Major & Teachers without ID experience would rely on their past experience \\
\hline 4: Study/ Live abroad & Expect more awareness of cultural differences. May site experiences \\
\hline $\begin{array}{l}\text { 5: Favorite activities as a } \\
\text { student }\end{array}$ & Will include favorite activities in a class \\
\hline $\begin{array}{l}\text { 6: Interaction with } \\
\text { teachers }\end{array}$ & Hi Power Distance cultures may indicate less interaction. \\
\hline 7: Comfort with Unknown & Uncertainty Avoidance \\
\hline
\end{tabular}

The survey was responded to by a total of 11participants representing five different cultures. The majority of the participants, 4 out of 11, were from the United States. Seven out of the eleven had experience living or working abroad.

In the introductory survey the expectation was that high Power Distance cultures would respond to question six (how much interaction did you have with your teachers) with the choice "They talked I took notes" and low Power Distance cultures to respond that "The teacher encouraged questions". In reality there were more participants that chose "It depended on the class". To evaluate Hofstede's Individualism/Collectivism 
ranking, question five asked about the favorite activities in class. The expectation was that individualistic cultures would prefer activities that were individual. The majority of participants indicated some form of discussion or group work as being their favorite activity.

A result of the method of selecting the participants four out of the twelve participants' were, or currently are, in an Instructional Design and Technology program. This may have had an impact on their answers to the questions. Their exposure to a classroom environment outside their background culture may have an impact on their design style. One of the areas this research is focusing on is the impact that current training in Instructional Design has on instructional design. Do teachers who are creating their own lesson plans without any instructional design background rely more on their cultural background when creating instruction?

Table 4 below was created using the responses to question 4 , understanding preferred activities.

The responses were divided into group/individual activities and active/passive activities. It could be expected that the American participants would have a preference for 'individual' activities given the high score on Hofstede's Model of Cultural Dimensions. It was also anticipated that there would be a slightly lower Power Distance score. The data suggests that questions four and five show a preference for group activities. Further it could be expected that the American participants would cite more encouragement to speak compared to Asian cultures. Since there would have been an age difference the power distance may have been greater. It could also mean that there was a difference in the teaching style during which the participants were in their primary education. This will 
be something that must be considered when designing the methods section for the next project. There were a variety of majors, with five being in Instructional Design.

Table 18: Question 5 Personal Preferences
\begin{tabular}{|l|l|l|l|}
\hline Group & Individual & Active & Passive \\
\hline Discussion & Independent Projects & Presentations & Reading \\
Part 4 & Part 2 & Part 1 & \\
Part 9 & & Part 7 & \\
\hline Small group & & Round Table & Listening to \\
projects & & Part 8 & Lectures \\
Part 5 & & P15 \\
Part 6 & & & \\
\hline
\end{tabular}

It was possible to conduct interviews with several of the participants using a chat on the site. These interviews were done within one week of the survey being conducted. These interviews allowed the participants to expand, and clarify information given in the survey. As an example, to encourage the participant to discuss their thoughts about instructional design they were asked to design the perfect class. This was divided up into what the teacher would do, what the students would do, and how they would expect them to engage the content. They would expect the student to negotiate and come up with ideas. This participant expected engagement of the content through small group activities, and reflective writing. In this case the subject being taught was English to Speakers of Other Languages, so the choice of engagement reflected this idea. This participant reflected an awareness of their own culture when asked about the types of activities they would use in class. They responded "Some women can't work with men.", referring to the Muslim (or Islamic) culture where there are stricter gender roles. In conclusion, being able to interview the participants was useful in understanding how their cultural values were reflected in their design and teaching style. 


\section{The Initial Design}

The submission of an initial design sample served to establish a baseline of the participants' design strategies. This information would be combined with the results of the initial survey to provide a more in depth understanding of the participant's individual cultural identity. For the initial design sample Participants were presented with a scenario, a target audience and, and a suggested topic to be taught. The design sample was graded using a rubric developed to look for elements of Hofstede's Model. The scorers were asked to read through the design sample set and look for key words and concepts that would be used to give a score to the design sample. For example, if the participant gave explicit objectives in their sample, then this could indicate a high Uncertainty Avoidance ranking. 
Table 19: Initial Design Sample Overview

\begin{tabular}{|c|c|c|c|c|}
\hline Participant & Sequence & Activities & Key Words & Holiday \\
\hline Part 1 & $\begin{array}{l}\text { Attention } \\
\text { Overview } \\
\text { Presentation } \\
\text { Survey/end }\end{array}$ & $\begin{array}{l}\text { Read/Discuss } \\
\text { Decorate Tree } \\
\text { Gift Exchange } \\
\text { Eat Dinner }\end{array}$ & $\begin{array}{l}\text { Group work } \\
\text { Discuss } \\
\text { Clear objectives }\end{array}$ & Christmas \\
\hline Part 2 & $\begin{array}{l}\text { Attention } \\
\text { Overview } \\
\text { Groups }\end{array}$ & $\begin{array}{l}\text { Lecture } \\
\text { (introduction) } \\
\text { Discussion } \\
\text { Small groups }\end{array}$ & & Thanksgiving \\
\hline Part 4 & $\begin{array}{l}\text { Introduction } \\
\text { Hands on } \\
\text { Speaker } \\
\text { Attend FW }\end{array}$ & $\begin{array}{l}\text { Discussion } \\
\text { Group Activity } \\
\text { Craft }\end{array}$ & & $\begin{array}{l}\text { Independence } \\
\text { day of Ghana }\end{array}$ \\
\hline Part 5 & $\begin{array}{l}\text { Introduction } \\
\text { Speakers }\end{array}$ & $\begin{array}{l}\text { Video } \\
\text { Individual } \\
\text { Research } \\
\text { Assessment }\end{array}$ & & $\begin{array}{l}\text { Independence } \\
\text { Day of } \\
\text { America }\end{array}$ \\
\hline Part 6 & $\begin{array}{l}\text { Introduction } \\
\text { Hands on } \\
\text { Discussion }\end{array}$ & $\begin{array}{l}\text { Direct instruction } \\
\text { Individual } \\
\text { assignment } \\
\text { Craft }\end{array}$ & Venn Diagram & $\begin{array}{l}\text { Day of the } \\
\text { Dead }\end{array}$ \\
\hline \multicolumn{5}{|l|}{ Part 7} \\
\hline Part 8 & $\begin{array}{l}\text { Investigate } \\
\text { Discussion } \\
\text { Presentation }\end{array}$ & $\begin{array}{l}\text { Introduction } \\
\text { Individual } \\
\text { assignment } \\
\text { Presentation }\end{array}$ & Compare & $\begin{array}{l}\text { Spring } \\
\text { Festival in } \\
\text { China }\end{array}$ \\
\hline Part 9 & & & & $\begin{array}{l}\text { General } \\
\text { Holiday }\end{array}$ \\
\hline Part 11 & $\begin{array}{l}\text { Discussion } \\
\text { Lecture } \\
\text { Comparison } \\
\text { Written Essay }\end{array}$ & $\begin{array}{l}\text { Video Footage } \\
\text { Individual } \\
\text { project }\end{array}$ & & \\
\hline Part 13 & $\begin{array}{l}\text { Lecture } \\
\text { Group Work } \\
\text { Quiz }\end{array}$ & $\begin{array}{l}\text { Small group } \\
\text { Discussions }\end{array}$ & $\begin{array}{l}\text { Previous Knowledge? } \\
\text { Compare/contrast } \\
\text { List reasons }\end{array}$ & Christmas \\
\hline Part 14 & Introduction & & & $\begin{array}{l}\text { General } \\
\text { Holiday }\end{array}$ \\
\hline Part 15 & $\begin{array}{l}\text { Group Work } \\
\text { Discussion } \\
\text { Oral/written } \\
\text { assignment }\end{array}$ & & & $\begin{array}{l}\text { New Years } \\
\text { Day }\end{array}$ \\
\hline
\end{tabular}

Chart Color Code:

Red: Discussions

Green: Group Work

Blue: Individual Projects

Brown: Crafts/Hands on 


\section{Choice of Topic:}

The scenario provided a general topic of "Favorite Holiday" and general information about the training requirements. While some structure was necessary to focus the design it was important to allow the participants to have some control over the design. The demographics of the student base they were preparing for was given. Activities provided:

The table above listed the types of activities that the participant used. There were lecture based activities, which comprised of teacher/SME directed activities. Individual activities were classified as those activities where students worked individually. Small group and group activities were classified as those that required the students to work together. Hands on activities were those activities where students created something. Assessment activities were those activities that elicited new knowledge from the student.

\section{Part 2 Intervention: Educational Belief Quizzes}

\section{Moodle and Selective Release}

The intervention consisted of four quizzes, set up in Moodle, to evaluate the participants' educational beliefs. Using the Moodle selective release functions the participants would be able to view one of two PowerPoint presentations after taking each quiz. There was one version available if the participant received a high score (over 50) on their quiz, and another if they scored low (under 50). In using the Coin Model neither side was considered correct or incorrect.

The feedback provided examples of countries that were both high and low on the dimension. A basic introduction to who Hofstede was, and what his research involved, 
was provided. Participants were also given examples of things to consider given their results. The intervention was created to create self-awareness in the participant without establishing one side as correct.

There were four educational belief quizzes used to assess the pre-intervention status of the participants. What we were interested in was how the individual participants would reflect the National Standard established by Hofstede in the 1960's. There were several American participants, so we were able to compare the results of the surveys. The results showed that individual rankings do not always coincide with national rankings, which was also found in the initial study conducted in 2010. (Hando, 2012)

Table 20: Student Response VS. Hofstede's Reported Ranking

\begin{tabular}{|c|c|c|c|c|}
\hline & Power Distance & $\begin{array}{l}\text { Individualism/ } \\
\text { Collectivism }\end{array}$ & $\begin{array}{l}\text { Masculinity/ } \\
\text { Femininity }\end{array}$ & $\begin{array}{l}\text { Uncertainty } \\
\text { Avoidance }\end{array}$ \\
\hline $\begin{array}{l}\text { Part } 1 \\
\text { American }\end{array}$ & $\begin{array}{l}50 \\
40\end{array}$ & $\begin{array}{l}65 \\
91\end{array}$ & $\begin{array}{l}65 \\
62\end{array}$ & $\begin{array}{l}51 \\
46\end{array}$ \\
\hline $\begin{array}{l}\text { Part } 2 \\
\text { American }\end{array}$ & $\begin{array}{l}27 \\
40\end{array}$ & $\begin{array}{l}65 \\
91\end{array}$ & $\begin{array}{l}51 \\
62\end{array}$ & $\begin{array}{l}50 \\
46\end{array}$ \\
\hline $\begin{array}{l}\text { Part } 5 \\
\text { American }\end{array}$ & $\begin{array}{l}30 \\
40\end{array}$ & $\begin{array}{l}58^{*} \\
91\end{array}$ & $\begin{array}{l}65 \\
62\end{array}$ & $\begin{array}{l}45 \\
46\end{array}$ \\
\hline $\begin{array}{l}\text { Part } 9 \text { An } \\
\text { American }\end{array}$ & $\begin{array}{l}\text { High } \\
40\end{array}$ & $\begin{array}{l}\text { Low } \\
91\end{array}$ & $\begin{array}{l}\text { High } \\
62\end{array}$ & $\begin{array}{l}\text { High } \\
46\end{array}$ \\
\hline $\begin{array}{l}\text { Part } 13 \\
\text { American }\end{array}$ & $\begin{array}{l}45 \\
40\end{array}$ & $\begin{array}{l}70 \\
91\end{array}$ & $\begin{array}{l}41 \\
62\end{array}$ & $\begin{array}{l}55 \\
46\end{array}$ \\
\hline $\begin{array}{l}\text { Part } 14 \\
\text { American }\end{array}$ & $\begin{array}{l}55 \\
40 \\
\end{array}$ & $\begin{array}{l}60 \\
91\end{array}$ & $\begin{array}{l}45 \\
62 \\
\end{array}$ & $\begin{array}{l}21 \\
46 \\
\end{array}$ \\
\hline $\begin{array}{l}\text { Part } 7 \\
\text { Nigerian }\end{array}$ & $\begin{array}{l}45 \\
80\end{array}$ & 30 & $\begin{array}{l}56 \\
60\end{array}$ & $\begin{array}{l}61 \\
55\end{array}$ \\
\hline $\begin{array}{l}\text { Part } 8 \\
\text { Chinese }\end{array}$ & $\begin{array}{l}41 \\
80\end{array}$ & $\begin{array}{l}37 \\
20\end{array}$ & $\begin{array}{l}31 \\
66\end{array}$ & $\begin{array}{l}70 \\
30\end{array}$ \\
\hline $\begin{array}{l}\text { Part } 11 \\
\text { Japanese }\end{array}$ & $\begin{array}{l}40 \\
54\end{array}$ & 46 & $\begin{array}{l}31 \\
95\end{array}$ & $\begin{array}{l}51 \\
92\end{array}$ \\
\hline $\begin{array}{l}\text { Part } 15 \\
\text { Canadian }\end{array}$ & $\begin{array}{l}55 \\
39\end{array}$ & $\begin{array}{l}45 \\
80\end{array}$ & 52 & $\begin{array}{l}40 \\
48\end{array}$ \\
\hline
\end{tabular}

Participant reported score above and Hofstede's reported score below 
While it was expected that the American participants would score similarly on the Educational Belief Quizzes some discrepancies must be pointed out. Participant 1 and Participant 2 showed differences on the Power Distance scale, even though they are both from America. This variation was similar to that found in the pilot study. What must also be pointed out is that the individualism/collectivism scale seemed to indicate a lower ranking than Hofstede reported.

Table 21: American Participants VS. Hofstede's Model
\begin{tabular}{|l|l|l|l|l|}
\hline & Power Distance & Individ/Coll & Masc/Femin & Unc/Avoi \\
\hline Hofstede & 40 & 91 & 62 & 46 \\
\hline Part 1 & 50 & 65 & 65 & 51 \\
\hline Part 2 & 27 (much lower) & 65 & 51 & 50 \\
\hline Part 5 & 30 & 58 & 65 & 45 \\
\hline Part 9 & 54 & 45 (Much lower) & 75 & 58 \\
\hline Part 13 & 45 & 70 & 41 (much lower) & 55 \\
\hline Part 14 & 55 & 60 & 45 & 21 (much lower) \\
\hline
\end{tabular}

Taking the data from these quizzes the next step was to see if the ranking on these quizzes were reflected in the initial survey and initial design sample.

\section{Part 3: Reflect and Redesign}

To establish the effectiveness of the intervention the participants were asked to reflect on the results of their Educational Beliefs Quizzes and then redesign their Initial Design Sample. The initial design sample would be compared to the redesign for changes.

As the main purpose in this study was to establish if an intervention to increase cultural self-awareness would change instructional design practices. Participants were encouraged to redesign their original design submission after considering what they learned in the intervention. Table ten below includes the sequence, activities, and notes on chances made in the final design submission. 
Table 22: Instructional Design Sample-initial and Revised Submissions

\begin{tabular}{|c|c|c|c|c|}
\hline Participant & Sequence & Activities & Changes & Notes \\
\hline Part 1 & $\begin{array}{l}\text { Attention } \\
\text { Overview } \\
\text { Presentation } \\
\text { Survey/end }\end{array}$ & $\begin{array}{l}\text { Read/Discussion } \\
\text { Decorate Tree } \\
\text { Gift Exchange } \\
\text { Eat Dinner }\end{array}$ & $\begin{array}{l}\text { Increased Group } \\
\text { work } \\
\text { Discussion }\end{array}$ & Christmas \\
\hline Part 2 & $\begin{array}{l}\text { Attention } \\
\text { Overview } \\
\text { Groups } \\
\text { Groups }\end{array}$ & $\begin{array}{l}\text { Lecture } \\
\text { Discussion } \\
\text { Small groups }\end{array}$ & $\begin{array}{l}\text { Comparison } \\
\text { Share what they } \\
\text { learned }\end{array}$ & Thanksgiving \\
\hline Part 4 & $\begin{array}{l}\text { Introduction } \\
\text { Hands on } \\
\text { Speaker } \\
\text { Attend FW }\end{array}$ & $\begin{array}{l}\text { Introduction } \\
\text { Discussion } \\
\text { Craft }\end{array}$ & $\begin{array}{l}\text { Group } \\
\text { assessment } \\
\text { Individual } \\
\text { Assessment }\end{array}$ & $\begin{array}{l}\text { Independence day of } \\
\text { Ghana }\end{array}$ \\
\hline Part 5 & $\begin{array}{l}\text { Introduction } \\
\text { Speakers }\end{array}$ & $\begin{array}{l}\text { Video } \\
\text { Individual } \\
\text { Research } \\
\text { Assessment } \\
\end{array}$ & $\begin{array}{l}\text { Group work } \\
\text { Comparison }\end{array}$ & $\begin{array}{l}\text { Independence } \\
\text { Day of America }\end{array}$ \\
\hline Part 6 & $\begin{array}{l}\text { Introduction } \\
\text { Hands on } \\
\text { Discussion }\end{array}$ & $\begin{array}{l}\text { Lecture } \\
\text { Individual craft } \\
\text { Discussion }\end{array}$ & $\begin{array}{l}\text { Included Venn } \\
\text { Diagram }\end{array}$ & Day of the Dead \\
\hline \multicolumn{5}{|l|}{ Part 7} \\
\hline Part 8 & $\begin{array}{l}\text { Investigate } \\
\text { Discuss } \\
\text { Presentation }\end{array}$ & $\begin{array}{l}\text { Introduction } \\
\text { Discussion } \\
\text { Presentation }\end{array}$ & Comparison & $\begin{array}{l}\text { Spring Festival in } \\
\text { China }\end{array}$ \\
\hline Part 9 & $\begin{array}{l}\text { Introduction } \\
\text { Discussion } \\
\text { Group project }\end{array}$ & & Individual project & General Holiday \\
\hline Part 11 & $\begin{array}{l}\text { Discussion } \\
\text { Lecture } \\
\text { Comparison } \\
\text { Written Essay }\end{array}$ & $\begin{array}{l}\text { Video Footage } \\
\text { Individual project }\end{array}$ & & \\
\hline Part 13 & $\begin{array}{l}\text { Lecture } \\
\text { Group Work } \\
\text { Quiz }\end{array}$ & $\begin{array}{l}\text { Small group } \\
\text { Discussions }\end{array}$ & $\begin{array}{l}\text { Elicit Previous } \\
\text { Knowledge } \\
\text { Compare/contrast } \\
\text { List reasons } \\
\end{array}$ & Christmas \\
\hline Part 14 & $\begin{array}{l}\text { Clear learning } \\
\text { objectives }\end{array}$ & $\begin{array}{l}\text { Icebreaker/group } \\
\text { Mini lecture } \\
\text { Discussion }\end{array}$ & $\begin{array}{l}\text { Add additional } \\
\text { resources to the } \\
\text { lecture } \\
\text { Example of } \\
\text { expectations in } \\
\text { sample scenario } \\
\text { Mentioned Risk } \\
\text { Avoidance } \\
\text { cultures }\end{array}$ & General Holiday \\
\hline Part 15 & $\begin{array}{l}\text { Group Work } \\
\text { Discussion } \\
\text { Oral/written } \\
\text { assignment }\end{array}$ & $\begin{array}{l}\text { Intro activity } \\
\text { Discussion } \\
\text { Instructor presentation } \\
\quad \text { Group oral assessment } \\
\end{array}$ & $\begin{array}{l}\text { Individual written } \\
\text { assessment }\end{array}$ & New Year's Day \\
\hline
\end{tabular}




\section{Chapter Summary}

The overall results of the study showed that the cultural awareness training did influence the number of instructional design choices made by the participants. What is interesting is that they did not eliminate any design decisions from their initial sample, but instead chose to add based on what they learned. 


\section{CHA P TER 5: DIS CUSSION}

Cultural self-awareness for instructional designers and teachers makes an impact on instructional design decisions. In a world where globalization has enabled students the opportunity to study online from China, Germany, or anywhere in America, cultural selfawareness is increasingly crucial to student success. When different cultures come together different educational expectations are brought into the classroom. These differences can cause confusion for everyone involved, and create a less effective learning experience.

One way to increase this cultural self-awareness is through the use of Hofstede's Model of Cultural Dimensions as a tool to discuss our expectations. This research, follows up on a pilot study, was interested in two questions. First “ Does explicit training in awareness of culture impact design decisions?" Secondly, do Instructional Designers who are self-aware of their own cultural-boundedness include different instructional choices/design decisions?

This study used a mixed method design to collect and analyze data. An introductory survey along with an initial design sample formed the baseline. The intervention consisted of twenty questions using Hofstede's Model of Cultural Dimensions. Based on the individual student response, each student was provided a PowerPoint explaining the results. Finally, the participants were asked to take this knowledge and redesign their initial design sample. A follow up interview of seven questions was done with the participants through a chat. 
The initial design sample used a scenario; see Appendix 2, to prompt the participants on the student base and purpose of the lesson. Participants were asked to create a lesson using their favorite holiday. The focus of the prompt was the types of activities that they would choose to incorporate into their design.

The first research question was simply "Does the intervention cause the participants to make changes in their design." To assess the intervention we compared the initial design sample follow-up design. The data shows (90\%) that the redesigned design sample usually included additional design decisions based on their self-reflections. Only one sample did not make any changes, and indicated that a lack of time was a factor. Participant two, in their exit interview, admitted to liking individual activities, but also included some group work it "resembled real life".

The most popular change as, indicated by comparing the initial design sample with the final design sample, was the inclusion of more discussion using open-ended questions. For example, participant eight, whose sample lesson focused on the Spring Festival in China, wanted the students to discuss the importance of food during certain festivals. This was consistent with participant one, who expanded on the activities section of his design sample to include some group discussions. In participant one's initial survey they indicated that they enjoyed doing presentations, so this may have influenced this decision. Looking at Hofstede's Model these open ended questions could be linked to a lower Uncertainty Avoidance ranking in the classroom culture.

When participants were asked to describe an activity they would like to try, Participant 4, an American, indicated a willingness "to assess individual abilities rather than group work, and including a rubric so that students are aware of what is expected of 
them." Participant 2, also American, mentioned the way she normally held group activities

"Rotating small group activities. What I like about it is it allows people to work with different types of people. This, again, is a prep for real world because we don't always get to work with people we like or choose and this allows people to figure a way to work together with people regardless of compatibility. By rotating, they also aren't stuck with the same people."

The second question was "Do instructional designers who are self-aware of their own culture include different design choices?". From the comparison of the initial and final design samples, we know that the participants did alter their design. The data from the Educational Beliefs Quizzes suggests that that the participants reflected about their educational cultural beliefs. The Educational Beliefs Quizzes were a short series of quizzes to elicit the participants' feelings on cultural expectations in the classroom. They were based on four of Hofstede's Model of Cultural Dimensions.

We also found that they included new activities into their designs. However this did not create a situation where they felt they had to radically modify their initial design decisions. This was encouraging because it shows that the Coin Model Concept was working. Part of the goals of using Hofstede's model was to create a method of discussing cultural educational beliefs without resorting to 'right' and 'wrong'.

The design decisions made here illustrate that the ranking on the Educational Belief's Quizzes can be seen in the instructional design sample activities. There were six participants from America, so looking at their design samples should give us an idea of that typical expectations might be. Overall, the American participant design samples 
normally contained an introductory discussion/ice-breaker activity, a lecture activity, and a group activity. Participant nine, who scored the highest on the Uncertainty Avoidance Ranking, included more activities that would not require guesswork. Participant 14, the lowest scoring on the Uncertainty Avoidance Ranking, invited students to share, in the icebreaker, what they already knew about the topic (Holiday).

What is the most interesting here is that none of the participants took anything away from their initial design sample. This shows that they were confident in their initial design decisions, but the intervention made them think about other educational cultures. In this respect the use of the coin model has proved effective.

The researcher's experience in Japan, one of the motivators for this study, shows that this can happen through implicit means. At first the research went into the classroom process with the expectations of her American educational background. She wanted the students to speak up, and give their opinions. This resulted in confusion from the student base because they were used to the standard practices in Japan, which is lecture oriented, and higher uncertainty avoidance. To give a personal opinion, that might be contradictory from the teacher, was not acceptable. To modify her design the researcher had the students form a group opinion, which was acceptable.

The exit interview provided a chance to discuss with the participants what they felt they learned about themselves, as well as how the intervention functioned. A key piece of information elicited from the exit interview was that all of the participants knew that they had individual learning preferences. Participant number four indicated that he enjoyed discussions in class, which was not common in Ghana, thus he enjoyed the American system of education more. Participant number seven indicated that she enjoyed 
individual activities, but was now interested in including additional methods. Participant eleven had a background in international training, so she was aware of Hofstede's Model. She was aware that she liked to maintain control in the classroom, but that she could learn what students actually were thinking by giving up some of that control. "And as a trainer, less controlled activities also show me what students/learners are thinking about instead of me assuming that I know what they need/want".

When asked about the intervention, and how it functioned, participants indicated that the intervention questions were interesting. They enjoyed thinking about their learning style, and how it influenced their current design. One participant did not find the Moodle delivery system easy to use, but she admitted she was use to other systems.

One factor that must be considered is the participants' background culture, and taking into account how this might influence their willingness to participate in this project. Most of the participants had lived and studied abroad, which gave them experience with other cultures. This may have influenced their concept of what instruction should be.

\section{Limitations}

One limitation of this study is the small number of participants. We had six participants who were identified as American. This provided an opportunity to see some of the differences within that culture, while the other represented cultures were mostly were limited to single representatives for that culture. Looking at the diversity within the American representatives it is clear that a larger number of participants would be advantageous in getting a more sophisticated picture of how this might be affecting other cultures. 
A majority (75\%) of the participants had lived abroad. If they sought out the chance to live abroad then it might mean that they adapted easier than other people within their culture. During the exit interview, when talking to participants who had lived abroad the reasons included interest in that culture and wanting to experience that culture first hand.

Being open to the experience of living abroad shows a willingness to adapt to change. The choice of going to another country is not normally an experience that is taken on lightly. It requires a lot of preparation and commitment. The participants therefor were invested in the experience of living abroad. The research did not question how well they felt that they had fit in to their own culture, so this can not be affirmed.

How well they adapted to their cultural classrooms may have had an influence on their interest in other cultures. To account for this possibility cues were given in some of the exit interview question, and asked about an activity that they did not like doing as a child and would not include in their design. Participant number six mentioned rote memorization as something she was forced to do as a child, but did not like including in her design. Participant number four indicated that most of his classes were lecture oriented. In response he wanted to add more interaction in his classes. In the initial questionnaire given the participants were asked to remember their favorite activity as a child.

Most of the participants came from an IDT background. The fact that eleven of the students were in an instructional design degree program may have had some impact on their background culture. Through explicit and implicit experiences these students have looked at instruction in a new way. Those who were from other educational cultures 
had experienced the American higher education system, and had to adapt to the underlying expectations of that culture. The researcher herself has reported on her need to adapt to the educational culture of Japan while abroad.

This study also provides data that supports one of the criticisms of Hofstede's Model, which states that there are variations within a culture. Hofstede's model gives an overall score for a culture within each dimension. However, each individual's culturalboundedness will vary within that culture. This was illustrated in the response to several questions answers. For example looking at the response to Question 3 in the Introductory Survey (the amount of interaction they had with instructors) it was found that the American participants responded with a variety of choices: Two students chose lecture; two indicated that it depended on the class. One American student chose that discussion was encouraged in class by the instructor.

The accuracy of the rankings initially developed by Hofstede may have affected how the results were interpreted. The original research was done in the 1960's, which is a very different environment from our world today. This could be seen in the results of the Educational Belief Quiz on Independence. Hofstede's ranking places America at ninetyone, which is very high on the scale. The results of the participants educational belief quiz came in at a number closer to sixty-five. This could be due to the original study being done in a business setting, which may have different cultural expectations.

There has been some more recent research done that suggests revision to the original ranking proposed by Hofstede. (Wu, 2006) This was an attempt to update Hofstede's work and establish if the same results would be gathered under an educational setting. The findings were that work related culture does shift over time as social, 
political and economic aspects change. Changes in the femininity score could be attributed to the fact that a majority of Hofstede's initial participants were male (1984), while in the more recent study there were a majority of female participants. Changes in the labor pool as a social force may have shifted this score. Other changes were attributed to the work environment. Hofstede's original study was in a business setting where there were different cultural expectations from the educational environment Wu studied. As the world becomes more 'global' we may have to look at the concept of national culture more carefully, and the boundaries may become more flexible.

\section{Variations within a culture}

When Hofstede did his research he was looking at a National Culture. He did not account for variations and sub-cultures within a society. We can see the variations looking at individual participants within the same culture, and their answers to the initial survey questions. When looking at the amount of interaction students had it was found that there was variation within the culture. As was discussed above, one factor may have been the subject being taught. The teacher's expected lecture style may differ depending on the subject being taught. There may be more discussion expected in a literature class compared to a math class. Hofstede talks about three areas that form a person' culture; nature, personality, and national culture, therefore it would be interesting to understand how this influences their interest in educational topics.

The type of school the participant went to would also have an effect on their educational background culture. The U.S. public school system is as diverse as American itself. There are large inner-city schools and small, rural schools. This could be an 
important consideration in understanding the diverse response in the results of participants from an American background.

Other types of training, formal or informal, that the participants had may have influenced their educational beliefs. Exposure through family, or cultural communities, will produce different personal beliefs and educational cultures.

\section{Does Subject Matter Trumps Culture?}

The impact of the subject matter on instructional design is a factor that came up during this research. One of the initial survey questions involved the subject of encouraging questions in the classroom. The expectation was that cultures who were low Power-Distance would be more likely to encourage questions in the classroom. From the participant perspective the answer "It depends on the classroom" was chosen by nine out of fifteen participants across all cultures. It would be a good idea to look at the subject matter that is being taught to get a better understanding of how content may influence the design decisions.

As students we gravitate towards subjects that more closely match our individual cultural-boundedness ranking. Material, which is taught sequentially and where there is little room for deviation such as math, may create a teaching style that does not seem to encourage questions. Students whose personal Uncertainty Avoidance ranking may be higher might tend to enjoy this experience and excel in this classroom culture. If one could create a classroom where students perceive that they are able to ask questions, then it might be beneficial in reaching out to students who are low Power-Distance. 


\section{Future research}

An area that will be important to focus on, but which was not included in this study, is assessment methods. Does the educational culture expect students to be able to recite facts and figures to show that they have mastered the material? Do they want students to be able to discuss and argue their point of view to show that they understand the concept of the theory they are studying? Are answers marked as right or wrong, or are there shades of correctness? These questions could be linked to the dimensions in Hofstede's mode.

Another idea that would be interesting for further research is how instructional designers make use of this understanding about how culture affects their decisions. Will they use this to change the way they make decisions? Will they use it to work with people from other cultures to explain their reasoning behind wanting to include an activity? If they know that Japanese instructors are used to lecturing during class will they consider ways of initiating small steps towards an overall agreed objective? If they know that, in a language class, students should speak will they start by allowing time for group practice? If the administration is concerned about assessment can the designer show how online tools can be used? Can they use this understanding to understand why there may be reluctance to change?

One area of impact that this study could have would be in working with military veterans. Many veterans attempting to re-enter the civilian workforce have trouble adjusting to the lack of structure. The coordinator of the RBA Program works with military veterans returning to the classroom and has close interaction with the advocate for Veterans affairs. This applies to veterans returning to school to finish their 
undergraduate degree. The training they receive in the military is developed with a very rigid structure, so they become use to that educational culture. (Hando, 2012) Using Hofstede's Model of Cultural Dimensions the assumption could be that the military culture would rank higher on the Power Distance and Uncertainty Avoidance scale than mainstream American culture. To confirm this hypothesis newly discharged military personnel could be given the same intervention.

\section{Summary}

This research shows that explicit training in cultural self-awareness, using Hofstede's Model, encourages instructional designers to add additional design choices to their design tool-box. In training new instructional designers, who will be working in an environment where they will need to create training for participants from various cultures, this type of training could be useful. This self-awareness could also help instructional designers coming from one subculture be aware of other subcultures and create a design which functions better.

Instructional designers are taught to consider which tool is best for the educational objective they want to accomplish. Being aware of the influence of their own culture can help them choose the right tool to reach more of their target population. It can also give them additional tools for their "design box". While this can be learned through exposure to other cultures an intervention, such as used in this study, can start the process of understanding. 


\section{BIBLIOGRAPHY}

Ahern, T.C. (2010) Skipper. Unpublished computer software.

Boundless (N.D) High Culture. Retrieved May, 2013 from Boundless: https://www.boundless.com/sociology/definition/high-culture/

California State University Methods of Philosophy lecture 2: retrieved from http://www.csudh.edu/phenom_studies/methods_phil/lect_2.htm

CARLA, (N.D) What is culture? Center for Advanced Research on Language Aquistion. [Retrieved from] http://www.carla.umn.edu/culture/definitions.html)

Collis,Vingerhoets, and Moonen (1997) Educational Technology, 31(3), 41-44.]

Fischer Karin (August 2009). Number of Foreign Students in U.S. Hit a New High Last Year [retrieved from]: http:/chronicle.com/article/Number-of-Foreign_Studentsin/49142

Collis B., Vingerhoets, J., \& Moonen J. (1997). Flexibility as a Key Construct in European Training. British Journal of Educational Technology, 28 (3), 199-218

Fischer Karin (August 2009). Number of Foreign Students in U.S. Hit a New High Last Year [retrieved from]: http:/chronicle.com/article/Number-of-Foreign_Studentsin/49142

Fullan, M., Collinson, V., Cook, T., (2007). Organizational learning. Thousand Oaks, CA. Sage Publication Inc.

Hall, E.T. (1990). Understanding Cultural Differences, Germans, French and Americans, Yarmouth: Intercultural Press

Hando, (2012) Hofstede's Model of Cultural Dimensions: A Tool for Understanding How Background Culture Affects Instructional Designers. (unpublished) 
Hefling, K. (n.d.) "Study: Record number of foreign students hit US." Retrieved Oct. 2013 http://news.yahoo.com/study-record-number-foreign-students-hit-us050217743.html

Hofstede, G. (1984). National Cultures and Corporate Cultures. In L.A. Samovar \& R.E.

Hofsteade Dutch Social Scientist http://www.geert-hofstede.com/ and original use of model, time frame, etc.

Hofstede's Dimensions of Culture as Measurements of Student Ethnocentrisms: A Quasiexperimental study." Presented at the Annual Meeting of the Western States Communication Association, Portland, OR, February 10-14, 1995.

Hofstede, G. (1984). National Cultures and Corporate Cultures. In L.A. Samovar \& R.E.

Porter (Eds.), Communication Between Cultures. Belmont, CA: Wadsworth.

Khaslavsky, J. (1998). Integrating Culture into Interface Design. CHI 98, 18(23), 365366. Retrieved March 6, 2006 from ACM Digital Library.

McMillan, J., Schumacher, S., (1997). Research in education: A conceptual introduction. Addison-Wesley Educational Publishers Inc.

McNeill, D. (October 2, 2011) Japan Mulls Shifting Its Academic Year to Get in Step With the West. Chronicle of Higher Education. [retrieved from] http://chronicle.com/article/Ja-pan-Mulls-ShiftingIts/129226/?sid=gn\&utm_source=gn\&utm_medium=en

McSweeney, B. (N.D) http://geert-hofstede.international-businesscenter.com/mcsweeney.shtml

Mind Tools (n.d.) Hofstede's Cultural Dimensions: Understanding work place values around the world. Retrieved from (http://www.mindtools.com/pages/article/newLDR_66.htm)

Morrison, G., Ross, S., Kemp, J., (2004). Designing effective instruction. Hoboken, NJ. : John Wiley§Sons, Inc.

Ornstein, A., Hunkins, F., (1998). Curriculum, Foundations, Principles, and Issues. Needham Heights, MA. Allyn§Bacon.

Reeves (1992) Educational Technology Research and Development 1996, Volume 44, Issue 4, pp 85-104 
Reeves, T. (1992, September-October). Effective dimensions of interactive learning systems. Information Technology for Training and Education Conference (ITTE '92) (pp.99-113). St. Lucia, Brisbane: University of Queensland

Samovar, L., Porter, R., McDaniel, E., (2008). Communication between cultures. Belmont CA. Wadsworth Cengage Learning.

Schiffman, S. S. (1995). Instructional systems design. Five views of the field. In G.J. Anglin (Ed.), Instructional Technology: Past, present, and future. (2ed ed., pp. 119-127)., Englewood, CO: Libraries Unlimited, Inc.

Schuman, L (1996). Perspectives on Instruction. [on-line] Available: http://edweb.sdsu.edu/courses/edtec540/perspectives/perspectives.html

Signorini, P., Wiesmes, R. \& Murphy, R.; (2009). Developing alternative frameworks for exploring intercultural learning: a critique of Hofstede's cultural difference model. Teaching in Higher Education, V 14, Issue 3 pp. 253-264.

Simy J., Kolb, D. (2008) Are there cultural differences in learning style? International Journal of Intercultural Relations, Volume 33, Issue 1, Pages 69-85

Socratic Method. (n.d.). Dictionary.com Unabridged. Retrieved August 04, 2014, from Dictionary.com website: http://dictionary.reference.com/browse/Socratic Method

Stull, B., James (1995). Hofstede's Dimensions of Culture as Measurements of Student Ethnocentrism: A Quasi-Experimental Study.

The Hofstede Center (n.d.) Dimensions. Retrieved from http://geerthofstede.com/dimensions.html

Tapenis, M. Smith, G., White, J. (2009). Cultural diversity and online learning: A study of the perceived effects of dissonance in levels of individuality/collectivism and tolerance for ambiguity. Internet and Higher Education (2009) pp. 26-34.

Trompenaars, A. \& Hampden-Turner, C. (1993) Riding the waves of culture: understanding cultural diversity in business. London: Nicholas Brealey.

WU M.(2006). Hofstede's Cultural Dimensions 30 Years Later: A study of Taiwan and the United States. Western Illinois University

WVU IDT progrm (nd) Instructional Design and Technology Graduate degrees. retrieved from http://www.hre.wvu.edu/academics/graduate_programs/doctoral_degrees/instructi onal_degree_technology) 


\section{Appendix}

Appendix 1: Consent letter

\section{Dear Participant,}

This letter is a request for you to take part in a research project to assess how culturally bound design decisions affect instructional design. This project is being conducted by Antoinette Hando, EdD candidate in Technology, Learning and Culture at WVU under the supervision of Terence C. Ahern, Associate professor in the College of Human Resources and Education. This project is being done as part of her candidacy requirement. Your participation in this project is greatly appreciated and will take approximately 20 minutes to fill out a survey.

Your involvement in this project will be kept confidential as legally possible. All data will be reported in the aggregate. You must be 18 years of age or older to participate. I will not ask any information that should lead back to your identity as a participant. Your participation is completely voluntary. You may skip any question that you do not wish to answer and you may discontinue at any time. West Virginia University's Institutional Review Board acknowledgement of this project is on file.

I hope that you will participate in this research project, as it could be beneficial in understanding how implicit culturally bound design decisions affect instructional design. Thank you very much for your time. Should you have any questions about this letter or the research project, please feel free to contact Antoinette Hando at 304 216-2021, or by email at Toni.Hando@mail.wvu.edu.

Thank you for your time and help with this project.

Antoinette (Toni) Hando 
Appendix 2: Initial Survey

Background

1: What is your nationality?

2: What is your gender?

3: What is/was your major?

4: Have you studied or lived in a foreign country?

5: What were your favorite activities in class as a student?

6: In school how much interaction did you have with your instructors?

The instructor talked I took notes

The instructor encouraged questions in class

It depended on the class

7: If the teacher asked you a question in class and you did not know the answer how upset would you be?

Very

Somewhat

Neutral

Not at all

8: What kind of classes do you design or teach?

9: Are you the designer as well as the instructor?

10: How much experience do you have in instructional design?

$0-1$ years

1-3 years

3-5 years

Over 5 years

11: What is the age of your student base?

Ages 6-12

Ages 13-18

Ages 18+

Ages 18-24 
Appendix 3:

Initial Instructional Design Sample

Dear Participants

You are being asked to design a class for undergraduate students (18-24) years old. The topic will be an introduction to your favorite holiday in your culture. You do not have to develop the content, but instead consider how you will present the content. The purpose of this activity is to discover your individual design style.

\section{Scenario Overview}

You are being asked to design a one-hour seminar for undergraduate students (18-24) years old.

The topic will be an introduction to your favorite holiday in your culture. You do not have to develop the content, but instead consider how you will present the content. The purpose of this activity is to discover your individual design style. Below you will find an outline of the project that should help you in preparing your course.

Outline of Project

Identifying and Organizing Content

Topic(s)

One holiday from your country

Participant's needs

Understand the background of that holiday

Understand how it is celebrated

Distinctive features

Studying for a minor in your language/culture

Interested in knowledge from a "native" speaker

Identifying learners

Participant profile

Undergraduate student in a university setting

Male and female

Ages 18-24

Motivated by a personal interest in language/culture

Participant concerns

Learning about the culture before they study abroad

Have some previous knowledge of the culture from TV and media

Have taken traditional classes $40 \%$ have not taken online classes

Context of Seminar

Supported through the foreign language department

Students requested the seminar

20 students have signed up 
Voluntary attendance 


\section{Appendix 3: Educational Beliefs Quizzes}

You will now be asked about your personal design choices and beliefs. There are no right or wrong answers.

PDI (Power Distance Index) is the amount of tolerance in power distribution within a society. To what degree do members of that culture accept that power may be distributed unevenly? High PDI cultures may tolerate a degree of dictatorship from the leaders, or look up at the teachers as gurus and respect them accordingly. Low PDI cultures on the other hand, see very little gap between the higher-ups and subordinates and expect more equalities. These questions were designed using Wu's and Stull's surveys substituting teacher for employer.

Q1. Teachers should make most decisions without consulting students. H

Strongly agree

Somewhat agree

Neutral

Somewhat disagree

Strongly disagree

Q2. Students should participate in classroom decision-making. L

Strongly agree

Somewhat agree

Neutral

Somewhat disagree

Strongly disagree

Q3. At the undergraduate level it is all right for the student to call their teacher by their first name. L

Strongly agree

Somewhat agree

Neutral

Somewhat disagree

Strongly disagree

Q4. Students should not talk to their teachers about personal matters. H

Strongly agree

Somewhat agree

Neutral

Somewhat disagree

Strongly disagree

Q5. It is frequently necessary for instructors to use authority and power when dealing with students. $\mathrm{H}$

Strongly agree

Somewhat agree 
Neutral

Somewhat disagree

Strongly disagree 
Appendix 4: Individualism/Collectivism

The interviewer will use the following questions concerning your view of instruction. There are no right or wrong answers for this.

Individualism pertains to cultures with loose ties. Members are expected to look after themselves and their immediate kin. Collectivism believes in strong social ties where the key is trust and loyalty in relationships with other members, and beyond the immediate kin. IDV (Individualism Index) is used to measure this dimension. The questions used for this were developed by using two surveys. One developed by $\mathrm{Wu}$, and the other developed by Stull using Hofstede's Model. The researcher substituted teacher for employer.

Q1: It is important that students receive individual recognition at school for their work. (can also indicate masculine/feminine) I

Strongly agree

Somewhat agree

Neutral

Somewhat disagree

Strongly disagree

Q2: When developing a project, I would rather have students work as members of a group than as individuals. C

Strongly agree

Somewhat agree

Neutral

Somewhat disagree

Strongly disagree

Q3. It is important that students have free time to pursue their own interests. Assignments should allow students some individual choices. I

Strongly agree

Somewhat agree

Neutral

Somewhat disagree

Strongly disagree

Q4. Group success is more important than individual success. I create assignments so that most members of the group can succeed. C

Strongly agree

Somewhat agree

Neutral

Somewhat disagree

Strongly disagree 
Q5. An important part of the classroom experience is students working with other students as a group. C

Strongly agree

Somewhat agree

Neutral

Somewhat disagree

Strongly disagree 
Appendix 5: Masculinity/Femininity

In this section you will be asked a few questions regarding your views on instructional design. There are no right or wrong answers.

Hofstede ranked cultures either masculine or feminine according to what traits are considered acceptable. This refers to gender roles within a culture. A culture is masculine when roles are distinctive and such qualities as assertiveness, toughness, and materialism are the dominant qualities. As opposed to the feminine cultures where the roles are overlapping, and qualities such as modesty, softness and family orientation are dominant. The MAS (Masculinity Index) is used to measure these gender roles in different cultures.

1: Competition is a healthy part of the classroom. M

Strongly agree

Somewhat agree

Neutral

Somewhat disagree

Strongly disagree

2: I use rewards in class to motivate students. M

Strongly agree

Somewhat agree

Neutral

Somewhat disagree

Strongly disagree

3: I include methods to allow all students to participate in class. F

Strongly agree

Somewhat agree

Neutral

Somewhat disagree

Strongly disagree

4: I like direct instructional methods. M

Strongly agree

Somewhat agree

Neutral

Somewhat disagree

Strongly disagree

5: I include risk taking as part of the challenge of education. M

Strongly agree

Somewhat agree

Neutral

Somewhat disagree 
Strongly disagree 
Appendix 6: Uncertainty Avoidance

You will now be asked some questions regarding your design choices. There are no right or wrong answers.

Different cultures react with different levels of anxiety to the unknown. Strong UAI (Uncertainty Avoidance Index) cultures are suspicious to changes and consider 'different' as dangerous. Low UAI cultures are more open to new ideas and 'different' raises curiosity rather than alarm.

Q1. It is important to have assignment requirements and instructions spelled out in detail so that students always know what they are expected to do. HUA

Strongly agree

Somewhat agree

Neutral

Somewhat disagree

Strongly disagree

Q2. A teacher must be an expert in the field in which he or she teaches. HUA

Strongly agree

Somewhat agree

Neutral

Somewhat disagree

Strongly disagree

Q3. I enjoy taking risks. I encourage students to take risks when answering questions.

(I like using open-ended questions) LUA

Strongly agree

Somewhat agree

Neutral

Somewhat disagree

Strongly disagree

Q4. It is important to include flexibility in classroom design. LUA

Strongly agree

Somewhat agree

Neutral

Somewhat disagree

Strongly disagree

Q5. It is important to me to plan for the future very carefully. I plan for questions students might ask during the lesson. HUA

Strongly agree

Somewhat agree

Neutral

Somewhat disagree

Strongly disagree 


\section{Appendix 7: Sample PowerPoint Slides}

\section{CONGRATULATIONS!}

- Congratulations! You have scored on the high side of the Individualism/Collectivism scale. You prefer assessments that are individual in nature. You are more comfortable with individualistic activities, and feel that students should be judged on their own work. You probably encourage students to explore their interests. An advantage of this is it promotes individual motivation for learning. The other side of the coin is an educational belief in learning as a collective. This type of culture believes in the success of the group over the individual. An advantage of this is that it improves communication skills as students interact within their groups.

\section{WHAT WE NEED TO KNOW.}

- Geert Hofstede was a Dutch Social Scientist

- Worked at IBM

- Was interested in international business communication

- Developed 5 Cultural Dimensions

Power Distance

Independence

Masculinity/Femininity

Uncertainty Avoidance

Long Term/ Short Term orientation (added later) 


\section{RECOMMENDATIONS}

- You might try the following strategies in your lessons

- You might try including a group activity. To make the transition easier you could include roles in each group, so that students can have a specific part to do. You can determine what part of the grade is individual.

Encourage pride in the group they are associated with. (Design t-shirts for younger students, or group logos for older students)

\section{QUESTIONS}

- What is one thing you will take away from this PowerPoint?

-What is one question you have about this information?

- Did you find this information helped you understand yourself as an Instructional Designer? 
